\title{
Infantile colic: from basics to treatment
}

\author{
Haleh Masoodi $^{1}$, Siavash Rahimi ${ }^{2}$, Golvash Tavakolian $^{3}$, Sara Ahmadi Badi $^{4}$, Shahrbanoo Keshavarz Azizi raftar ${ }^{5}$, \\ Seyed Davar Siadat ${ }^{6,7}$ \\ ${ }^{I}$ Assistant Professor in Pediatrics, Department of Pediatrics, Imam Sajjad Hospital, Ramsar Pardis, Mazandaran \\ University of Medical Sciences, Sari, Iran. \\ ${ }^{2}$ General Practitioner, Department of Pediatrics, Imam Sajjad Hospital, Ramsar Pardis, Mazandaran University of \\ Medical Sciences, Sari, Iran \\ ${ }^{3}$ Medical Student, Faculty of Medicine, Mazandaran University of Medical Sciences, Sari, Iran \\ ${ }^{4}$ PhD of Microbiology, Microbiology Research Center (MRC), Pasteur Institute of Iran, Tehran, Iran \\ ${ }^{5}$ PhD candidate of Medical Bacteriology, Microbiology Research Center (MRC), Pasteur Institute of Iran, Tehran, \\ Iran \\ ${ }^{6}$ Professor of Medical Microbiology, Microbiology Research Center (MRC), Pasteur Institute of Iran, Tehran, Iran \\ ${ }^{7}$ Diabetes Research Center, Endocrinology and Metabolism Clinical Sciences Institute, Tehran University of Medical \\ Sciences, Tehran, Iran
}

\begin{abstract}
Infantile colic is a common condition among infants in which inability of caregivers to console their infants can lead to shaken baby syndrome, child abuse, depression and etc. Therefore it can lay a great economic burden in healthcare and social welfare systems. Even though it is highly prevalent, little agreement has been reached on the definition, pathogenesis or the optimal management strategy for infantile colic. In the past decade major leaps in understanding infantile colic has been taken by researchers. Although our understanding is greater than before, but novel treatments has yet to be introduced. The current review aims to delineate the Rome IV criteria definition, which is the latest published diagnostic criteria. Moreover, gastrointestinal, neurogenic, microbial and psychosocial factors that might contribute to the pathophysiology of infant colic are explored. Also, clinical assessment of infant with suspected colic is reviewed. Important aspect of the management of infant colic is further highlighted by this review. Management strategies, including dietary, behavioral, pharmacological and alternative interventions are also discussed.
\end{abstract}

Keywords: Infantile colic, Microbiota, Diagnosis, Treatment.

Cited as: Masoodi H, Rahimi S, Tavakolian G, Ahmadi Badi S, Keshavarz Azizi rafter S, Siadat SD. Infantile colic: from basics to treatment. Medical Science Journal of Islamic Azad University, Tehran Medical Branch 2020; 30(1): 1-15.

Correspondence to: Haleh Masoodi

Tel: +989123485877

E-mail: halemas1359@gmail.com

ORCID ID: 0000-0002-0520-1253

Received: 7 Jul 2019; Accepted: 13 Jan 2020 
مجله علوم بزشكى دانشگاه آزاد اسلامى

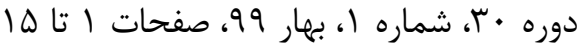

Review

Article

\section{كوليك شيرخوارگى: از يايه تا درمان}

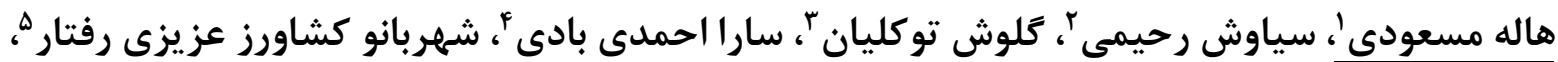

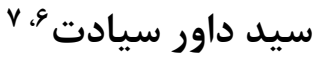

' استاديار، متخصص بيمارىهاى كودكان، ديارتمان كودكان بيمارستان امام سجاد (ع) رامسر، يرديس رامسر، دانشكاه علوم يزشكى مازندران، سارى، ايران

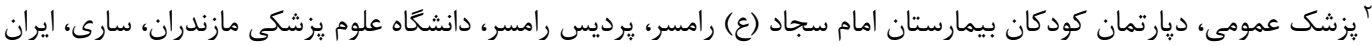

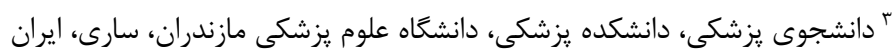

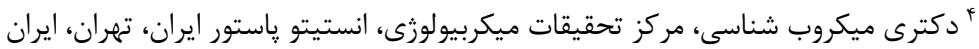

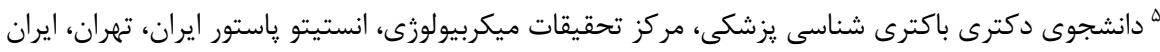

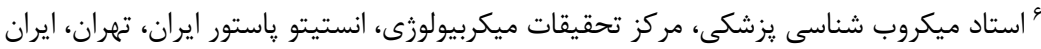

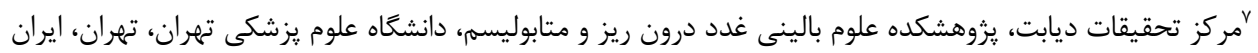

جكيده

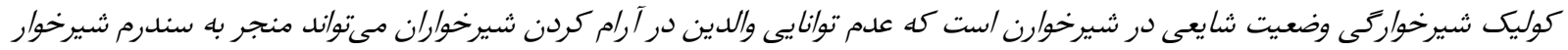

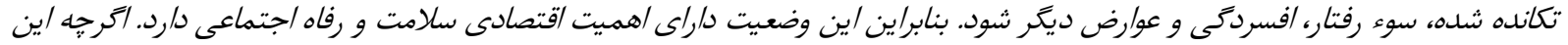

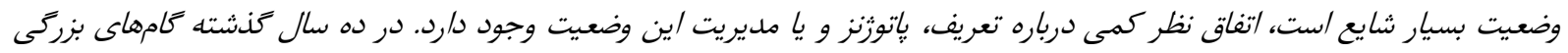

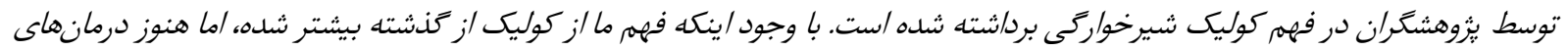

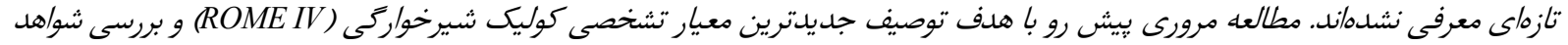

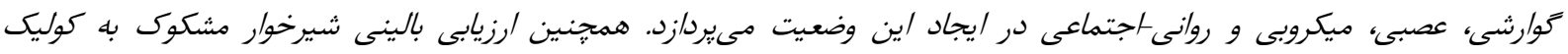

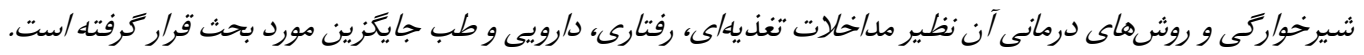

واثكان كليدى: كوليك شيرخواركى، ميكروبيوتا، بروبيوتيك.

سالم با تغذيه خوب، ماهيتى مقاوم، تسكين نايذير و بيش از ماز مقدمه

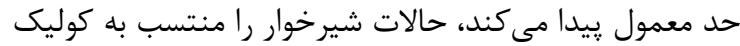

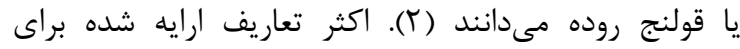

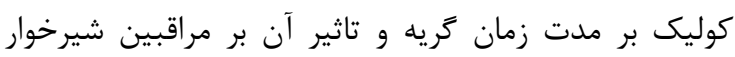

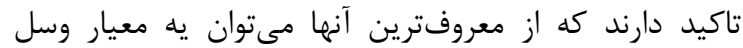

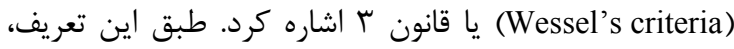

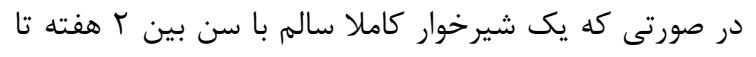

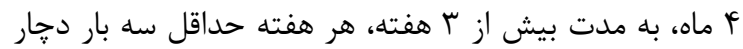

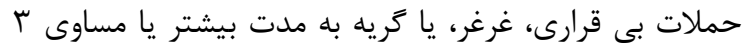
كلمه كوليك بركرفته از كلمه يونانى "kolikos" به معناى درد

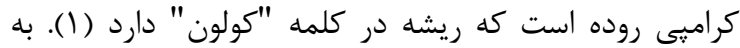

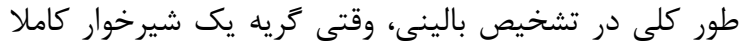

آدرس نويسنده مسئول: مازندران، شهرستان رامسر، ساختمان مركزى برديس رامسر دانشكاه علوم بز شكى

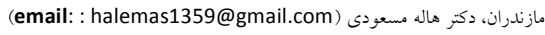
ORCID ID: 0000-0002-0520-1253 تاريخ دريافت مقاله:

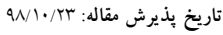


هستند (•). همجنين اختلالات خواب و حملات قشقرق در سنين يس از شيرخواركى بيش از ساير كودكان كزارش شده

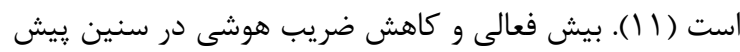
دبستانى نيز مواردى است كه برخى مطالعات كزارش كردهانداند

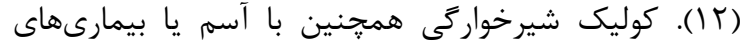
آتوييك دوران كودكى نيز در برخى مطالعات مرتبط بوده است

اخر جه بيش از نيم قرن، محققين تلاش كردند تا ارتباط اين

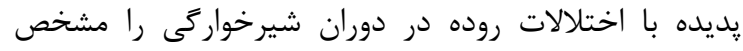

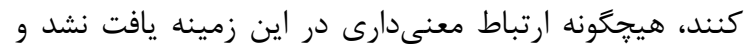

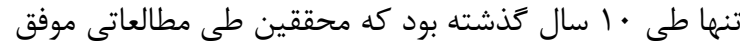

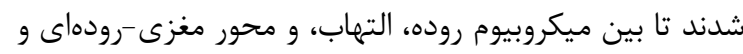
يديده كوليك ارتباطات معنىدارى كشف كنند (\$). همين طور بر اساس سبب شناسىهاى مشخص شده، راهكارهاى درمانى جديدى براى تسكين كريه و بهبود حالات شيرخواران

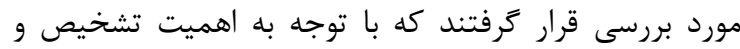

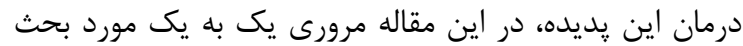

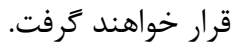

\section{مكانيسمهاى مطرح شده در ايجاد علايم}

در جدول r مكانيسمهاى مطرح شده در ايجاد كوليك شيرخوارگى ذكر شدهاند.

ميكروبيوم

صرف نظر از اتيولوزى نامشخص و קندعاملى كوليك نوزادان،

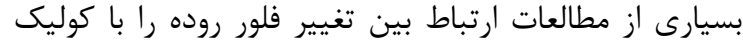
نوزادان نشان دادهاند. اين تاثير از طريق مسير سيخنالينگ اختصاصى روده - مغز و اثر متقابل بر فعاليتهاى دستخاه كوارش، هم در زمان بيمارى و هم بهبود، اتفاق مى افتد (If). ميكروبيوم روده جنين در دوران رحمى كاملا متاثر از
ساعت در روز شود، شيرخوار مزبور مبتلا به كوليك شناخته

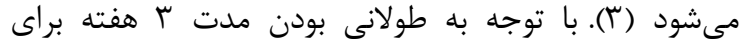

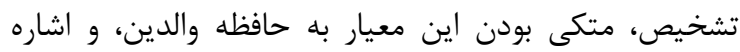

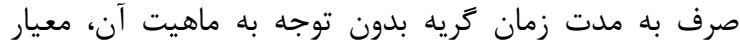
وسل به خصوص براى مقاصد تحقيقاتى بارها و بارها مورد

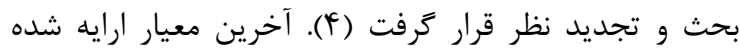
براى تعريف و تشخيص كوليك، معيار ROME IV است كه معيارهاى تشخيصى كوليك را براى مقاصد بالينى و تحقيقاتى

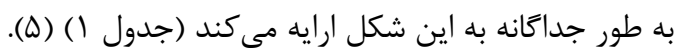

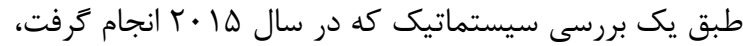

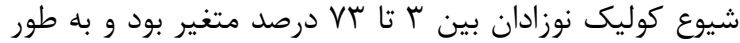

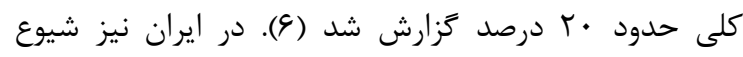

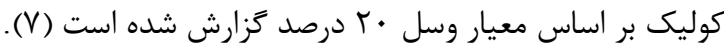
با اينكه ماهيت كوليك خوش خيم و خودمحدود است و وراس شيرخواران مبتلا از هر لحاظ كاملا سلامت بوده و تغذئيه مناسبى دارند، اين وضعيت عامل ايجاد اضطراب و خستخى إنى

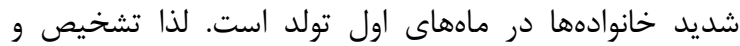

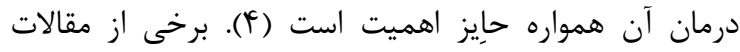
نشان دادهاند كه كوليك شيرخواركى عامل ايجاد افسردگى إنى

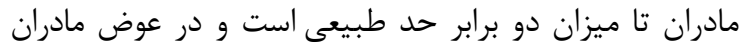

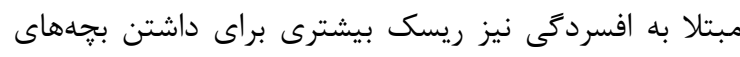

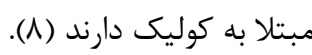
مطالعات نشان داده اند كه كريه كردن نوزادان مبتلا به كوليك اريك همجنين مىتواند باعث خاتمه زودرس شيردهى، تغذيه بيش

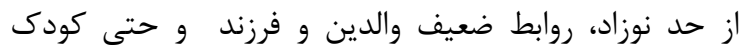

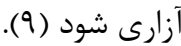

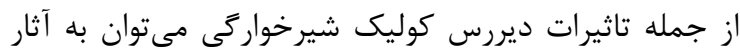

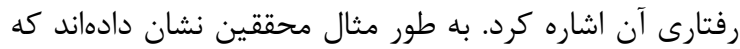

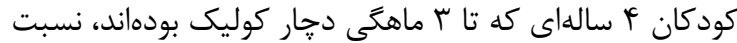
به ساير كودكان هم سن خود به لحاظ عاطفى آسيب يذيرتر

جدول ا. تشخيص كوليك شيرخواركى بر اساس معيار ROME IV (a)

تشخيص كوليك براى مقاصد بالينى بايد شامل تمام معيارهاى زير باشد

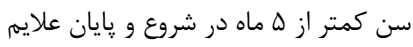

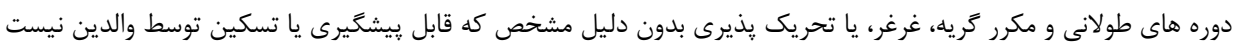

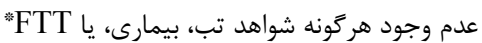

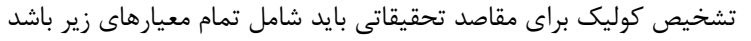
تمامى موارد فوق

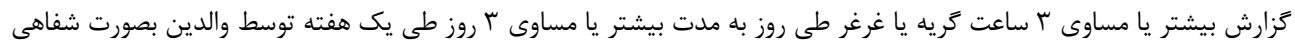

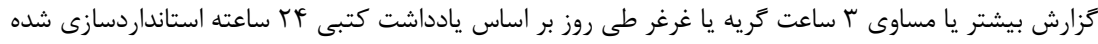


كوليك داشتهاند (I) (Y). بين يروتيوباكترها شيوع اشرشيا كولى

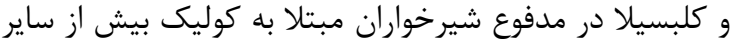

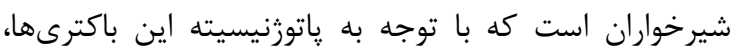

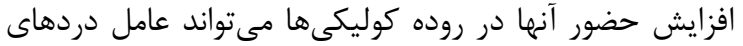

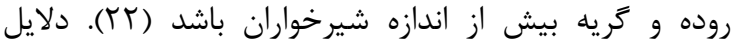
مختلفى براى توجيه اين ارتباط معكوس كفته شده كه از ازئ

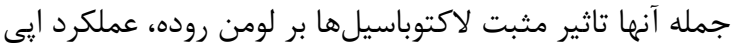
تليال، و حركات لوله كوارش است. همينطور به نظر مىرسد كه بيفيدوباكترىها و لاكتوباسيلها باعث تقويت عملكرد سيستم ايمنى روده شيرخواران مىشوند. علاوه بر اينكه احتمالا تاثيرات آنتاكونيستى بر باكترىهاى توليد كنينده كاز

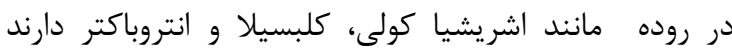

علاوه بر الكوى كلونيزاسيون باكتريال روده، دومين عاملى كه به نظر ميرسد مىتواند به صورت غيرمستقيم در ايجاد كوليك شيرخواركى نقش داشته باشد، توليد و تنظيم ترشح اسيدهاى

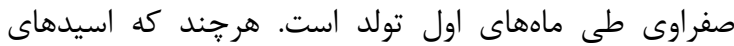

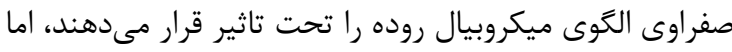

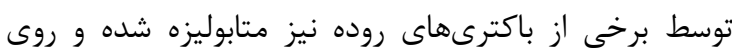

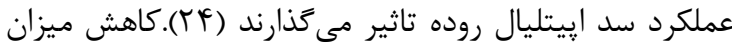
اينترالومينال اسيدهاى صفراوى، با ايجاد سوء جذب جرئ تربى و ساير مواد مغذى موجب اختلال در تركيب ميكروبيوم روده و در نتيجه بروز علايم كوليك مىشود. به نظر ميرسد عدم تمايز برخى از قسمتهاى קرخه انتروهياتيك (نقص عملكرد

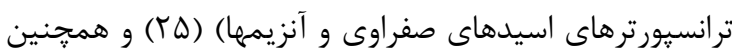
نارسى روده باريك به خصوص در قسمت ايليوم به ترتيب باعث كاهش توليد و تجمع اسيدهاى صفراوى در در محل رون روده

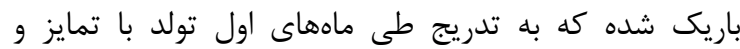
تكامل اين قسمتها، علايم كوليك نيز برطرف مىشوند (ع) (ب). عامل سومى كه فرض مىشود به طور غير مستقيم بر ايجاد علايم كوليك شيرخوارگى موثر باشد، عدم تمايز و تكامل سيستم عصبى روده است كه موجب اختلال در حس و حركت

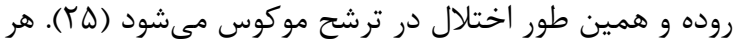

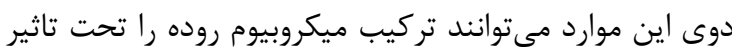
قرار دهند و موجب بروز علايم كوليك شوند. همجنين نشان داده شده كه اختلال تكامل سيستم عصبى كوارشى نوزادان نارس با ايجاد تاخير در تخليه معده، احتمالا يكى از علل ايجاد كريه و بى قرارى ماههاى اول تولد است (TV) (شكل الداد ).
ميكروبيوم روده مادر است كه آن هم ناشى از باكترىهاى

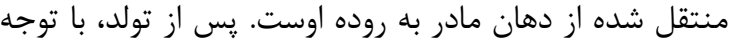

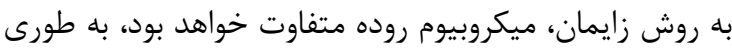
كه در صورت زايمان طبيعى انتروكوك و در صورت زايمان ماندان

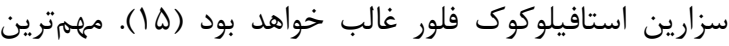

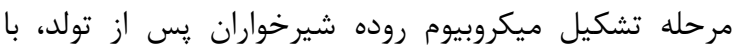
شروع شير مادر و كلونيزه شدن بيفيدوباكترى ها در روده اتفاق مىافتد و طى هفته اول يس از تولد، استافيلوكوك،

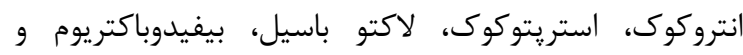
اعضاى خانواده انتروباكترياسه نيز به جمعيت ميكروبى روده

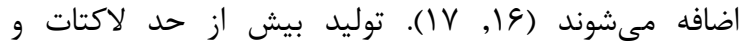

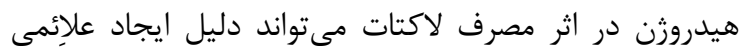

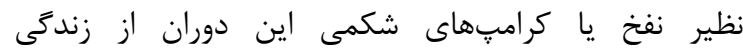
شيرخواران باشد (1) إن 19).

جدول r. سبب شناسى كوليك شيرخواركى

برهم خوردن تعادل ميكروبيوم روده اضطراب و نكخرانى خانواده

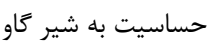

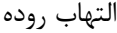

تغذيه با شير خشك رود ريفلاكس كاسترواسوفازيال افزايش موتيلين و سرتونين اختلال در فرايند درك درد مونين و سرتين عدم تحمل لاكتوز

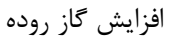

تجمع باكترىهاى احيا كننده سولفور مثل Desulfovibrio Piger با مصرف هيدروزن توليدشده توسط باكترىهاى فوق و وإس ايجاد سولفور باعث ايجاد دردهاى كولونيك و احساس ناراحتى شكم در اين دوران مىشود. مطالعات نشان دادهاند كه در جمعيت شيرخواران مبتلا به كوليك، باكترىهاى توليد كننده سولفور بيشتر از ساير شيرخواران است و شايد همين مساله،

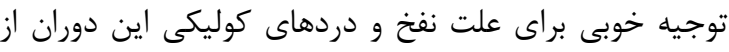
زندكى شيرخواران باشد (·r). محققين نشان دادهاند كه وجود

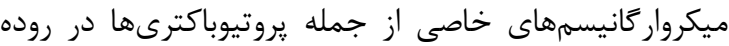

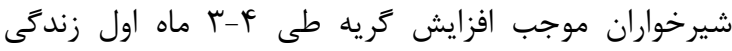

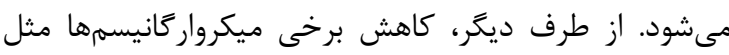
باكتروييد، اكتينوباكتريا و فرميكيوتها رابطه عكس بارئ علايم 
از ديكر مكانيسمهاى مطرح در ايجاد كوليك مىتوان به التهاب روده اشاره كرد. افزايش سطح كاليروتكتين مدفوع كه دئي

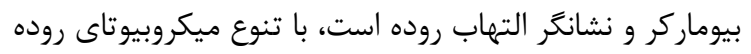
رابطه عكس دارد. باكترىهاى گرم منفى مثل اشريشيا كولى و و باكتروييد به علت داشتن لييو يلى ساكاريد درغشاى خارجى

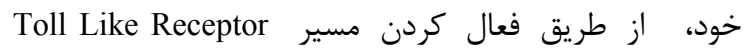

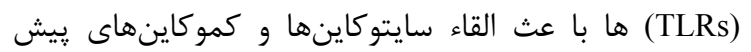
التهابى، ايجاد التهاب روده و در نهايت ايجاد علايم كوليك التهائ

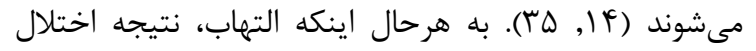

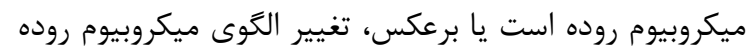

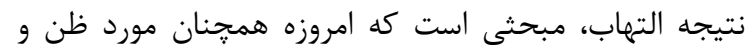

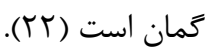

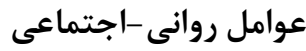

اين احتمال كه آيا اضطراب خانواده و انتقال اضطراب و ونكرانى

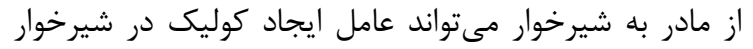

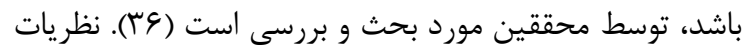
متناقضى بين اضطراب مادر و كوليك شيرخوارگى وجود دارد،

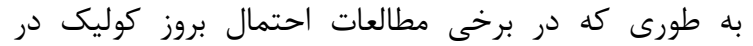

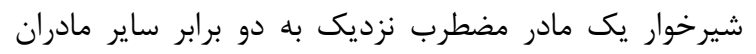

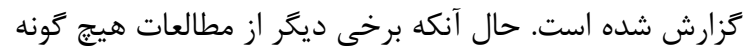

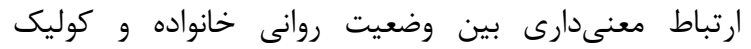

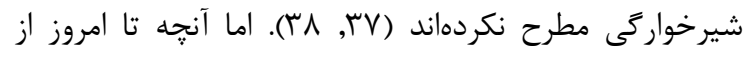

در رابطه با نوع تغذيه شيرخوار، از طريق شير مادر يا شير

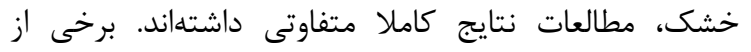

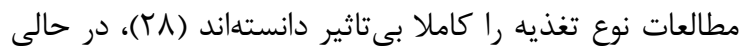
كه برخى ديكر شيوع كوليك در شيرخواران شيرمادرخوار را به ناته

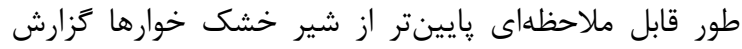

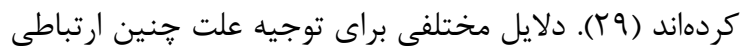

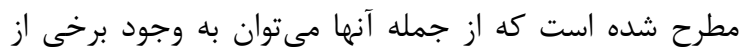

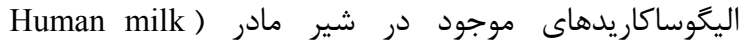
oligosaccharide,HMO كرد كه به عنوان يرهبيوتيك باعث رشد و افزايش تعداد بيفيدوباكترىها مىشوند كه احتمال نقش موثر آنها در كاهش

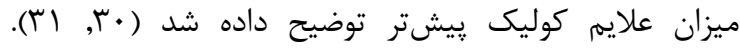
همجنين شير مادر حاوى IgA ترشحى، IgG و تركيبات ضد

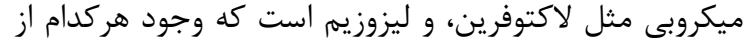
آنها بر انتخاب نوع باكترىهاى كلونيزه در كولون تاثيركذارند (Tr). به طور مثال طبق كزارش برخى از مطالعات، جمعيت بيفيدوباكترىها به خصوص كونه اينفانتيس ارتباط معنى دارى إنى

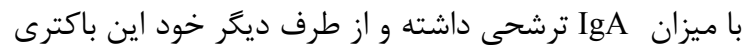

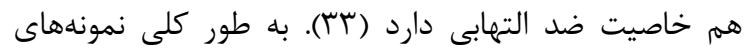

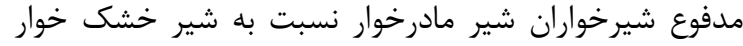

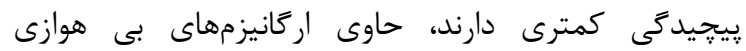

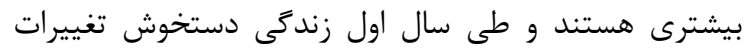

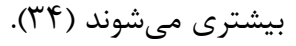

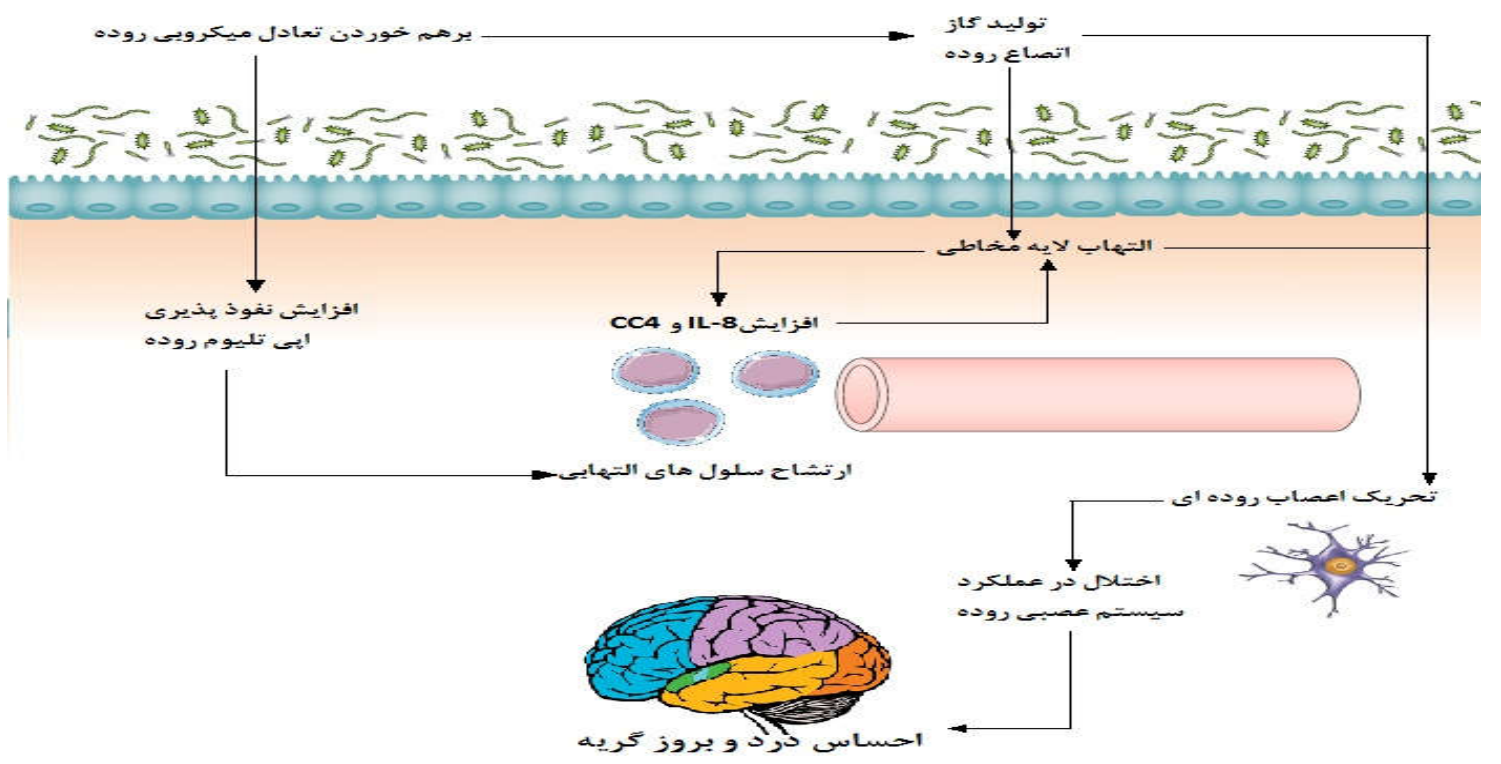

شكل 1. مكانيسم ايجاد كوليك توسط ميكروبيوتاى روده شيرخوار 
يكى از مطالعات اكثر مبتلايان به كوليك در آن مطالعه مبتلا

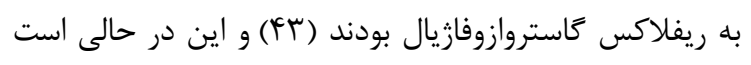

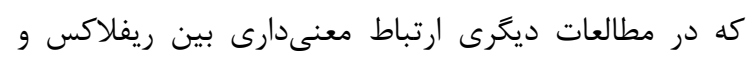

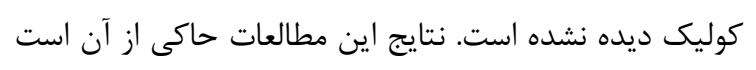

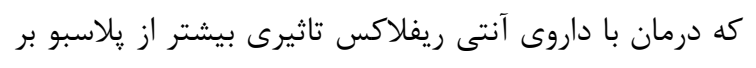

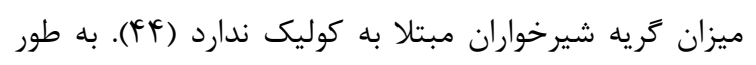

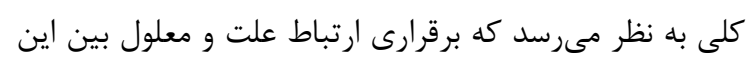

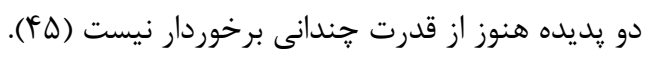

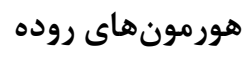
مطالعات مختلفى نشان دادهاند كه شيرخواران مبتلا به كوليك روده

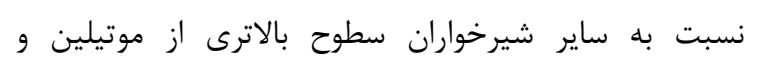

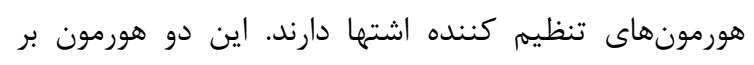

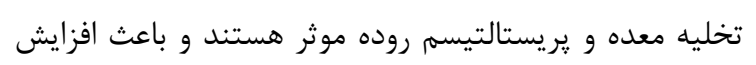
يريستالتيسم و احساس درد در روده مىشوند (4) بوان. همجنين

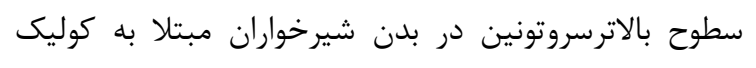

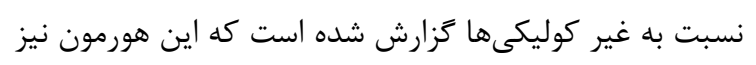

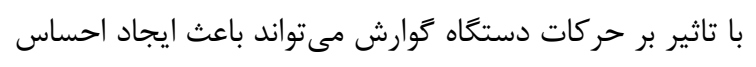

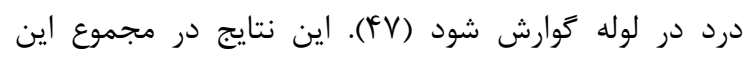

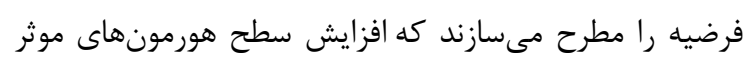
بر حركات لوله كوارش مى متواند در ايجاد علايم كوليك نقش إنش داشته باشد. عوامل موثر بر تكوين لوله عصبى

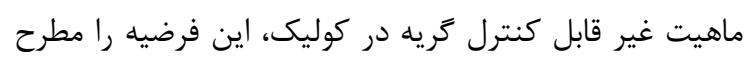

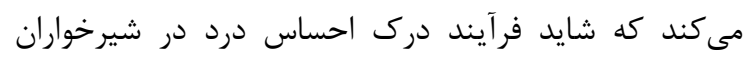

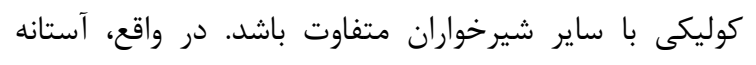

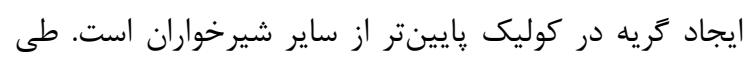

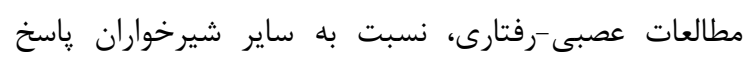

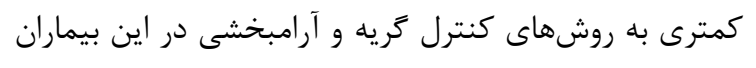

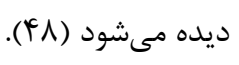

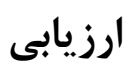

براى بررسى علت كريه شيرخواران، نياز به شرح حال و معاينه

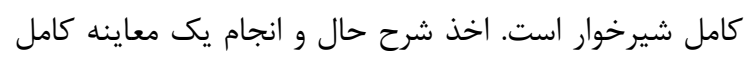

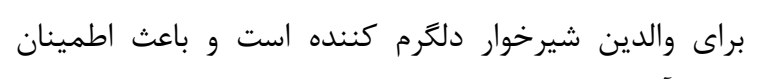

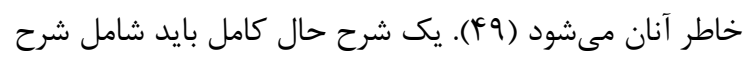

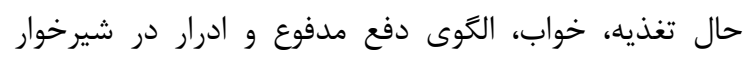

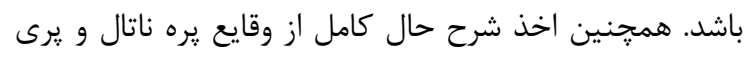

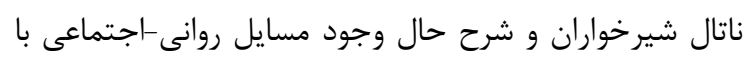

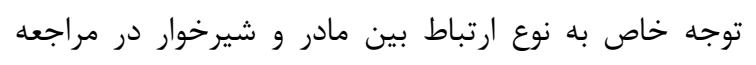

بررسى مقالات به نظر مىرسد، حاكى از وجود ارتباط معنى دار

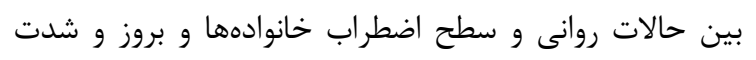

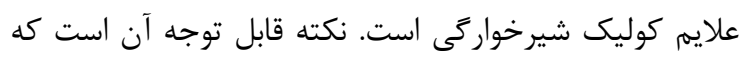

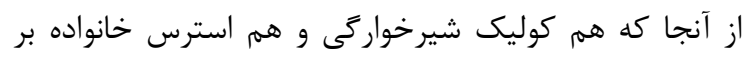
درك و ديدكاه والدين از ميزان كريه شيرخوار كار تاثيركذار است،

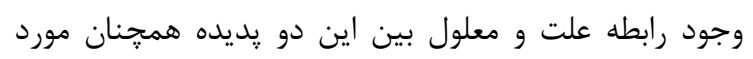

بحث است (†) بود رابطه علت

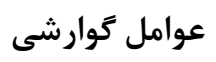

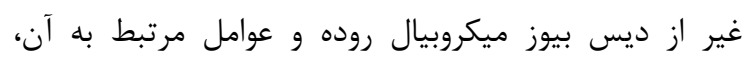

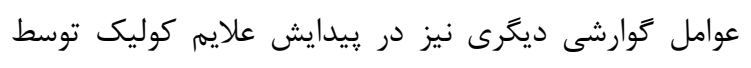
مطالعات مطرح شدهاند: واكنش هاى آلر زيك مطرح شداند:

يروتئين شير كاو يكى از نخستين مواد غذايى است كه دستخاه

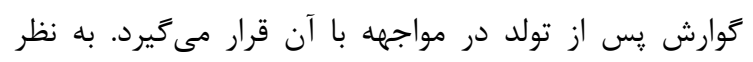

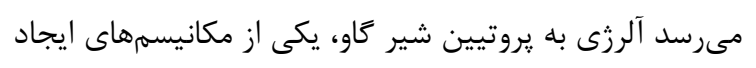

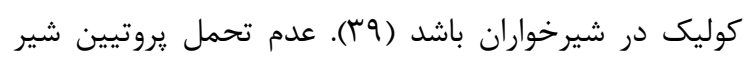

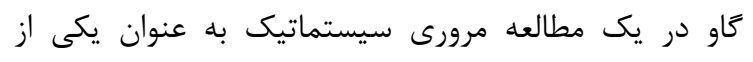

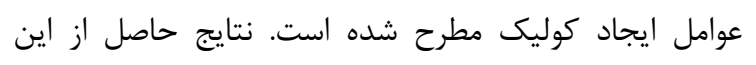

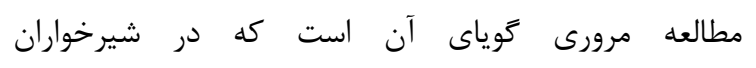
شيرمادرخوار، رعايت رزيم غذايى هييوآلرزنيك توسط مادر و و

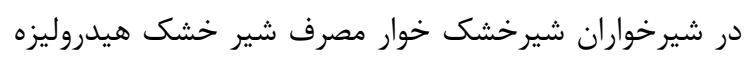

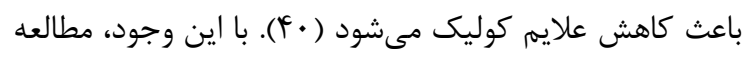

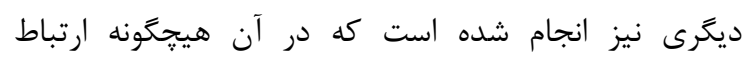

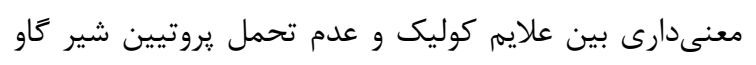

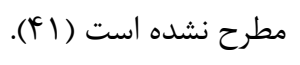
عدم تحمل لاكتوز نقص آنزيمى لاكتاز و سوء جذب ناشمل لاكتوز از آن، يكى ديخر از

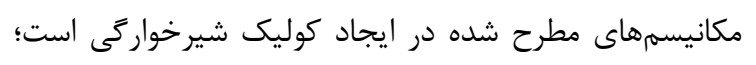

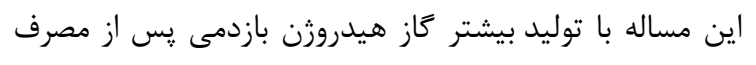

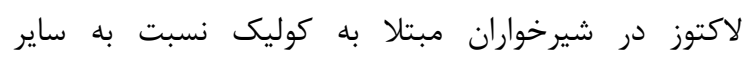

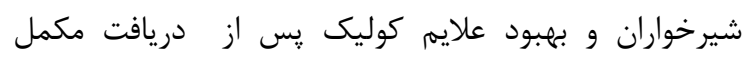

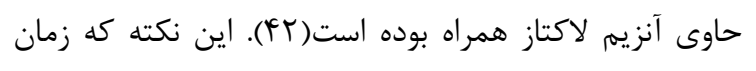

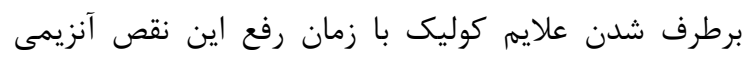

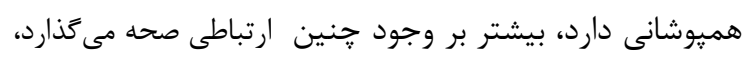

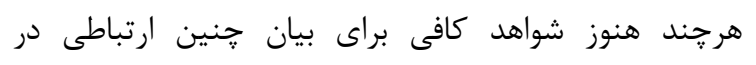
دسترس نيست.

\section{ريفلاكس كاستروازوفازيال}

نتايج مطالعات مختلف در مورد ارتباط ريفلاكس روارئ بال كوليك

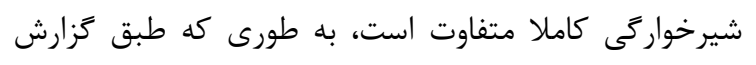


آتويى يا ميكَرن لازم است بررسىهاى بيشترى روى شيرخوار

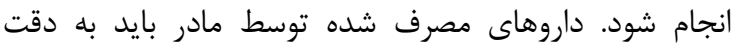
بررسى شوند، جرا كه برخى داروها باعث ايجاد آزيتاسيون و

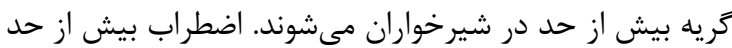

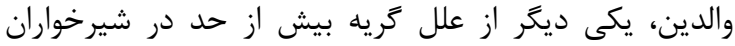

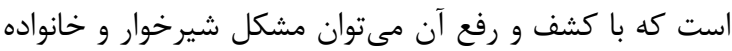
وى را تا حد زيادى برطرف كرد. همجنين كريه زياد در شيرخوار مادران دجار افسردىى يس از زايمان نيز ديده

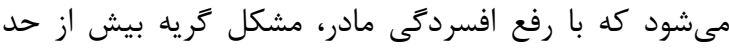

شيرخوار هم تا حدود زيادى مرتفع خواهد شد (؟).

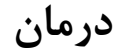

مداخلات درمانى كه در مطالعات بررسى شدهاند، در جدول r

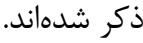

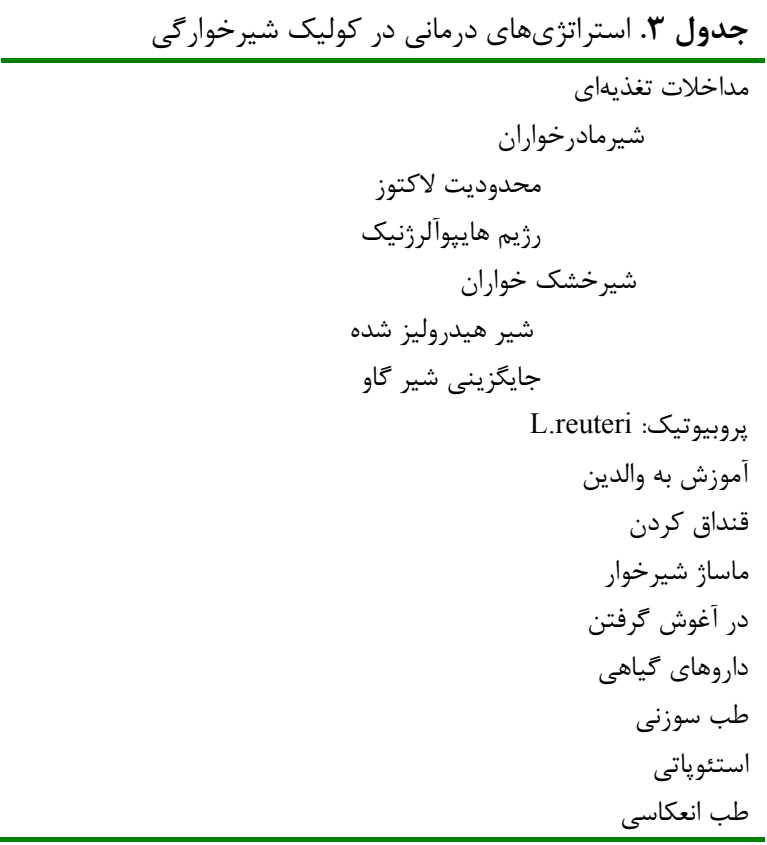

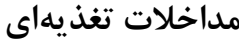

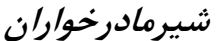
اين مساله كه آيا يروتئين شير كاو مترشحه در شير مادر

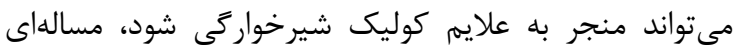
است كه همجنان مورد ظن و ترديد باقى مانده است (F) (F).

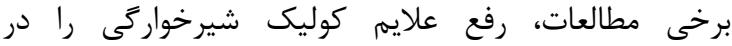
شيرخوارانى كه مادرانشان تحت رزيم محدوديت لاكتوز قرار

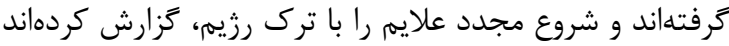

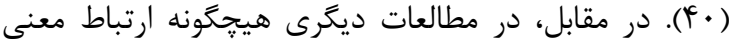

كنندكان ضرورى است. علاوه بر موارد فوق، در معاينه بالينى اين شيرخواران، دقت به وزن كيرى مناسب، وضعيت

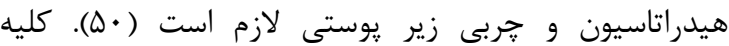

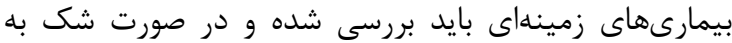

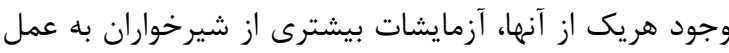
آيد. تشخيصهاى افتراقى زيادى براى كوليك شيرخواركى مطرح شده است كه تنها در صورت كنار كذاشتن همه اين تشخيصها مىتوان تشخيص كوليك را براى شيرخوار مطرح كرد. به طور كلى در شيرخوارى كه با شكايت كريه بدرن بدرن توجيه مراجعه مى كند، رد برخى تشخيصهاى مهرم ضرورى درى برى است. به عنوان مثال، در صورت وجود اسهال متناوب يا مياي انفجارى لازم است بررسىهاى تشخيصى لازم جهت كنار

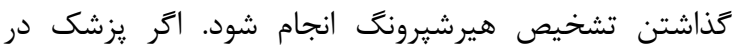
معاينه شيرخوار با علايم كوليك متوجه وجود تورم در ناحيه

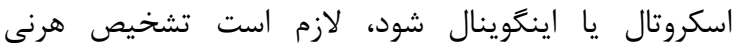

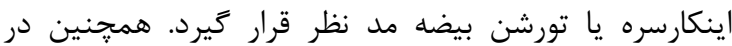
صورت ملاحظه تندرنس در لمس استخوانهاى بلند، كلاويكل

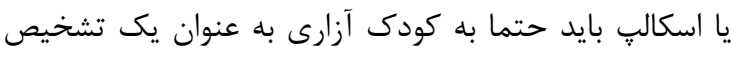
افتراقى مههم فكر كرد. در شيرخوارى كه در كنار علايم

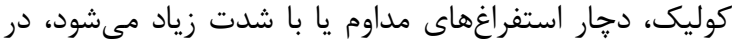

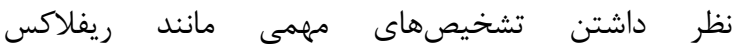

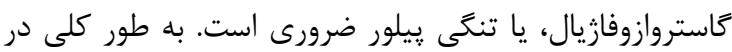

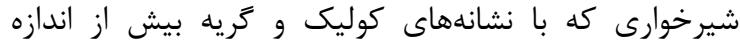
مراجعه كرده است، معاينه از نظر وجود فيشر آنال، خراش

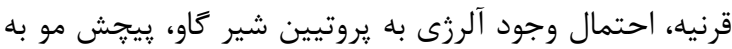

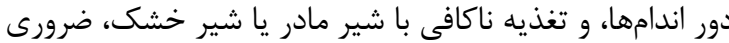

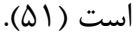

يكى از علايم خطر، ديستانسيون شكمى است كه مئوانواند

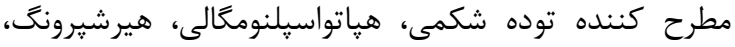
مالروتاسيون روده، ولولوس، و انتروكوليت نكروزان باشد. ديكر هيكر علامت خطر تب است كه مىتواند در زمينههايى مانند اوتيت مدياى حاد، آيانديسيت، باكتريمى، اندوكارديت، منتزيت، استيوميليت، ينومونى، سيسيس، عفونتهاى دستخاه ادرارى، و و عفونتهاى ويرال تنفسى همراه با علايم مشابه كوليك ديده شود. لتارزى علامت خطر ديكرى است كه در زمينه هايى مانند هيدروسفالى، مننزيت، سيسيس و هماتوم ساب دورال ديده

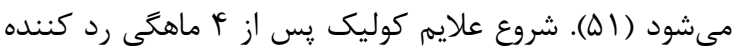
تشخيص كوليك شيرخواركى است. كاهش وزن از علايم خطر

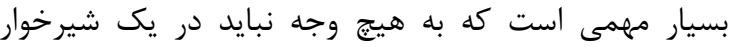
كوليكى ديده شود. همجنين در صورت وجود سابقه خانوادكى 
كوليك شيرخواركى، به خصوص در شيرخواران شيرمادرخوار

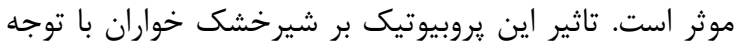

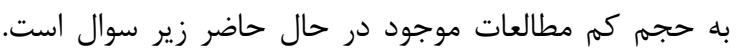

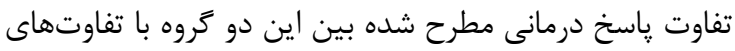

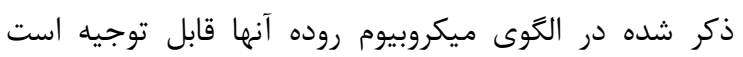

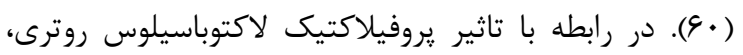
مطالعهاى انجام شده كه شيرخواران از جمله شيرخواران شير بران

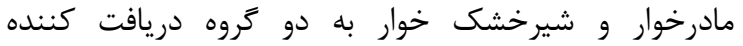

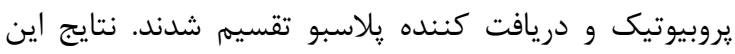

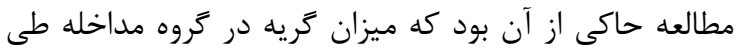

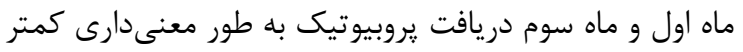
از كروه عدم مداخله بود ( (9).

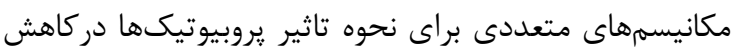

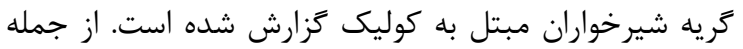
آنها مىتوان به كاهش التهاب روده با تعديل رسيتورهاى - Toll

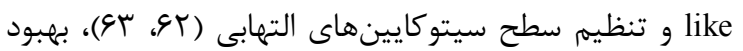
سد موكوزال و عملكرد إيى تليال روده، كاهش ترانسلوكاسيون

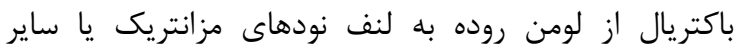

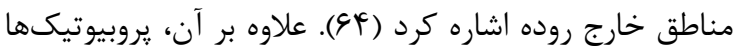

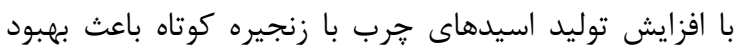

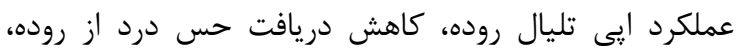

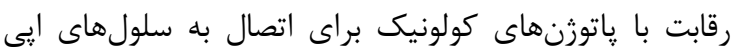

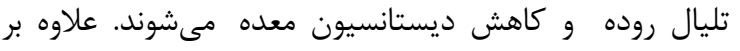

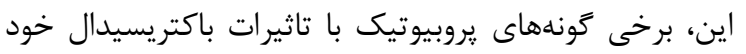

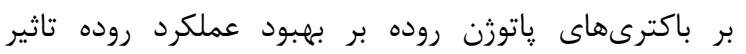

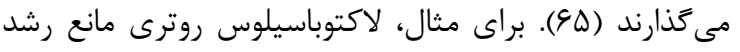

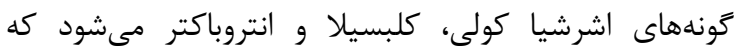
احتمال مى رود همين مساله، علت تاثير اين باكترى بر كالثر كاهش علايم كوليك شيرخواركى باشد (94).

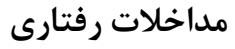
آموزش والدين و اطمينان بخشى مداري

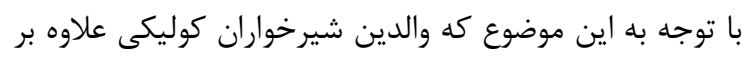

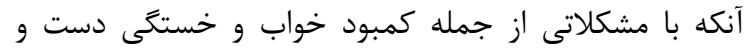

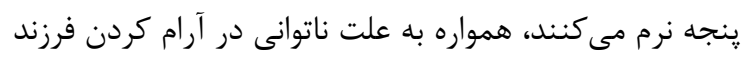

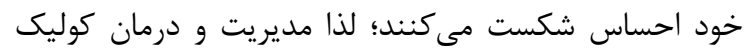

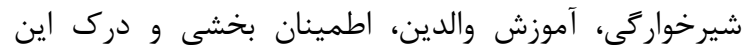
مشكل توسط يزشك متخصص كودكان امرى مهم است (SV)

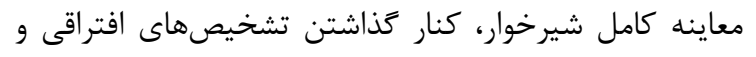

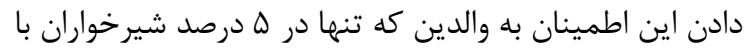
تظاهرات كوليك علل اركانيك يافت مىشود، اولين قدمها در
دارى بين محدوديت لاكتوز و رفع علايم كوليك مطرح نشده است (AT). همجنين نتايج برآمده از ساير مطالعات، اين

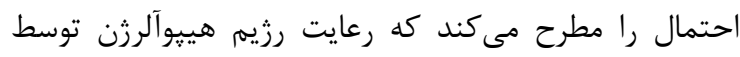

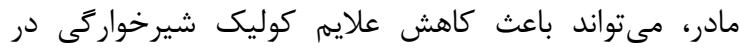

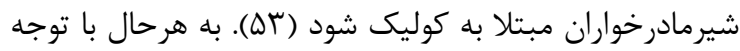

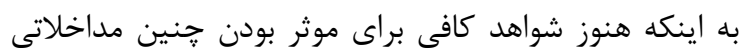

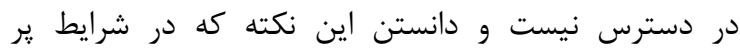
اضطراب خانواده شيرخواران كوليكى رعايت خنين رزيمهاي

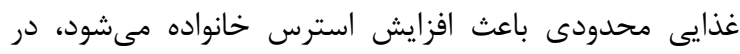
حال حاضر رعايت جنين رزيمى توصيه نشده است. شيرخشك خواران

نتايج حاصل از برخى مطالعات، نشان دادهاند كاند كهان استفاده از

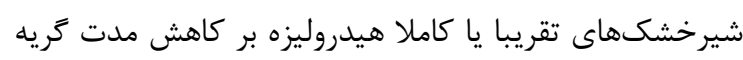

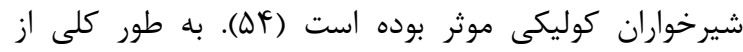

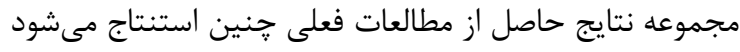

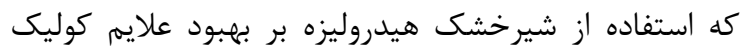
شير خواركى موثر است (هQه). شيرخشكهاى با پايه سويا نيز

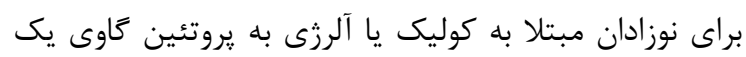

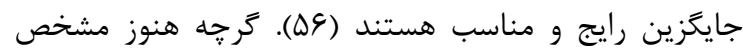
نيست كه بهبود حاصل، صرفا نتيجه قطع ثروتيين شير كاو

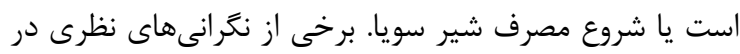

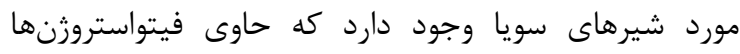
هستند كه ساختار شيميايى مشابه هورمون جنسى زنانيانه استروزن است. نكرانىهايى وجود دارد مبنى بر اينكه افزايش

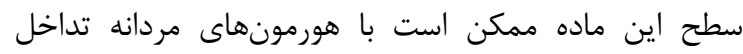

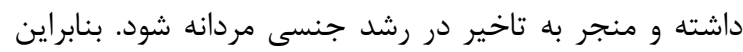

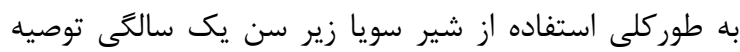

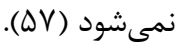

يروبيوتيك ندئ نيون يروبيوتيك در تعريف، شامل ميكرواركانيسههاى زندهاى است

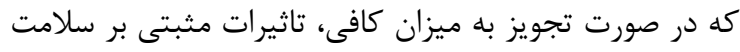

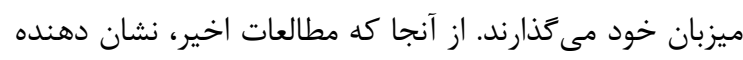

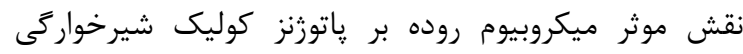
هستند، امروزه مصرف يروبيوتيك به عنوان يك دئ درمان بحت بحثن

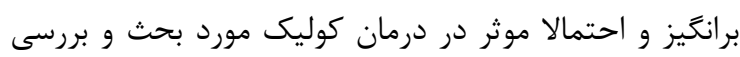

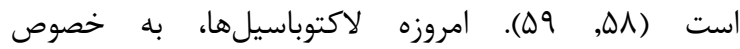
لاكتوباسيلوس روترى و بيفيدو باكترىها شايعترين يروبيوتيكهاى مطرح در درمان كوليك هستند (هᄉ). نتايج متاآناليزى كه اخيرا انجام شده كوياي كان آن آن است كه

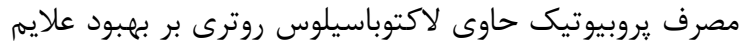


مصرف لاكتاز جهت درمان عدم تحمل لاكتوز در شيرخواران

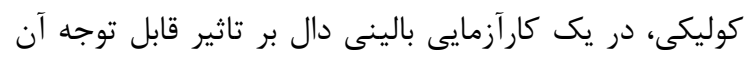

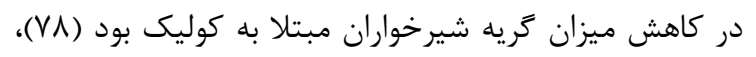

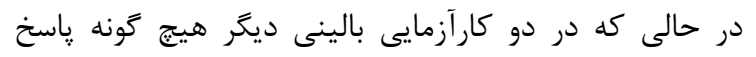

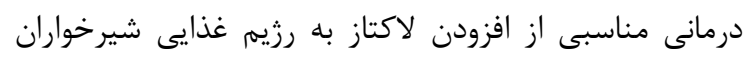

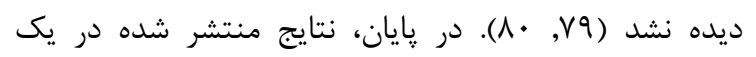

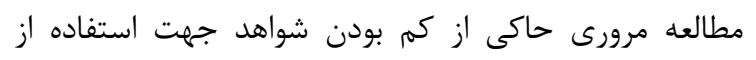

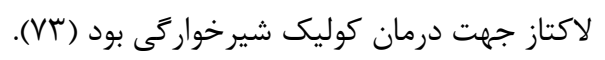

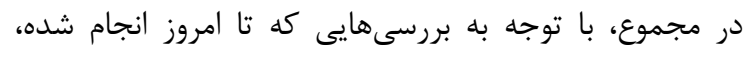
متناقض بودن نتايج مطالعات و كم بودن شواهد فعلا استفاده بـ بـاه

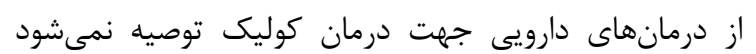

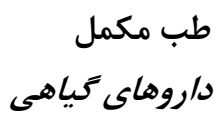

اين احتمال كه شايد استفاده از داروهاى كياهى حاوى رازي لفانهانه،

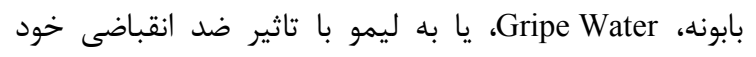

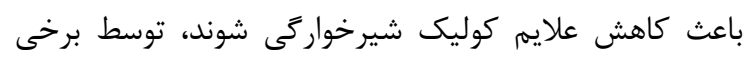

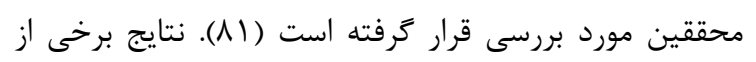

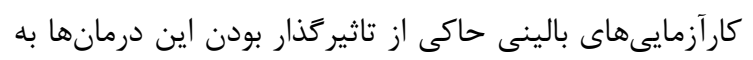

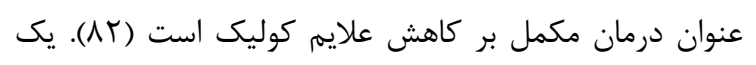

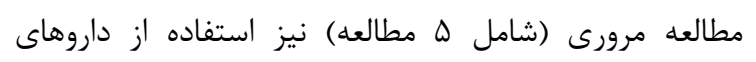

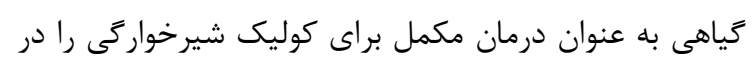

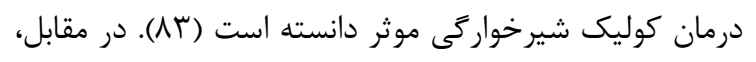

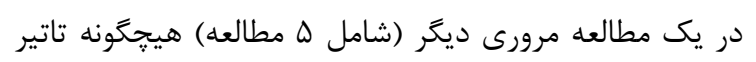

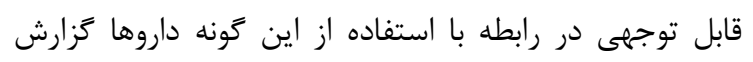

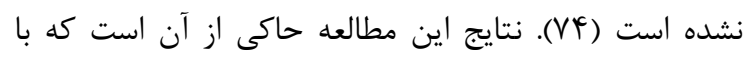

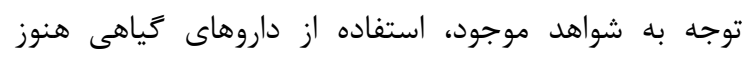

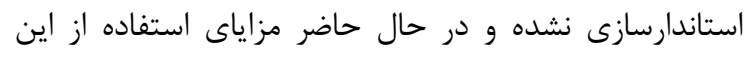

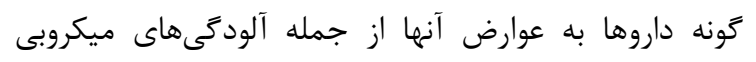

$$
\text { طب سوزنسى ندارد (AF). }
$$

اينكه آيا طب سوزنى قادر است از طريق تاثيرات بازدارنده خود

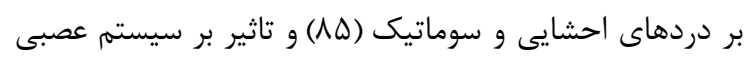

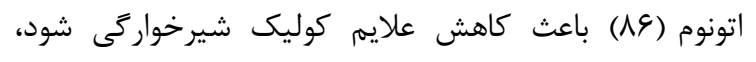

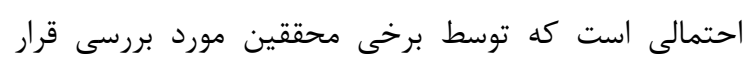

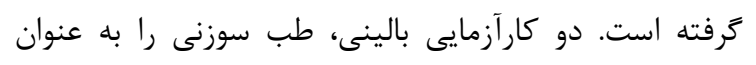

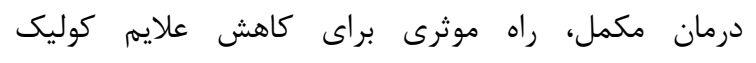

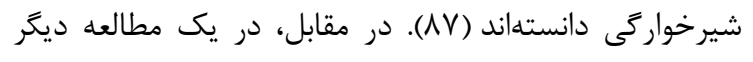

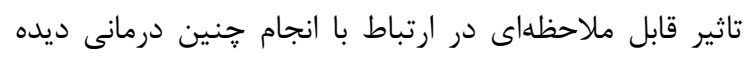

درمان و مديريت اين بيمارى است (9٪). آموزش ميزان

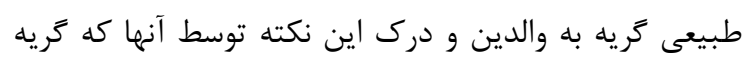

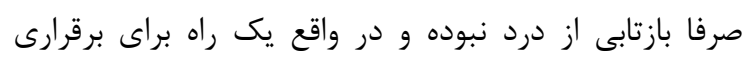

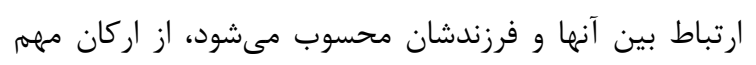

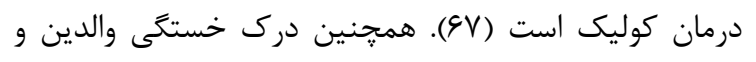

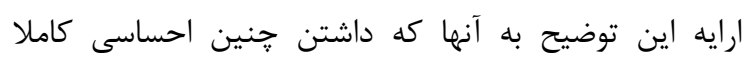

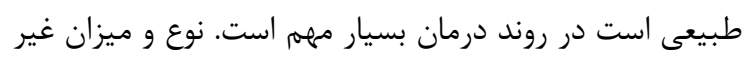

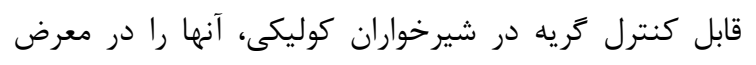

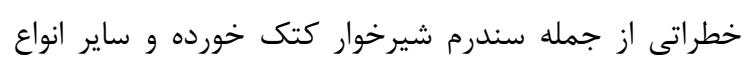

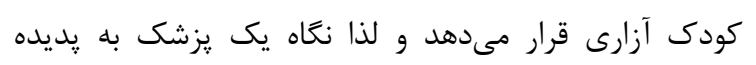

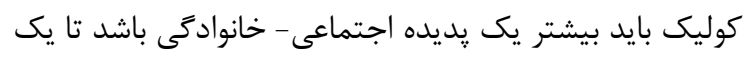

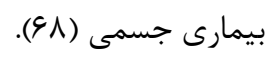
تغييرات رفتارى در يك مطالعه مرورى كه تأثير مداخلات رفتارى براى كاهش

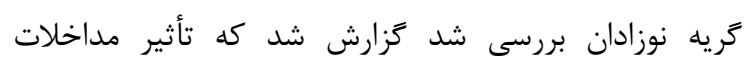

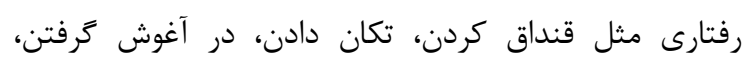

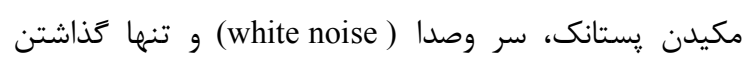

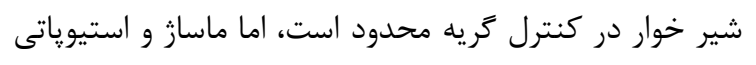

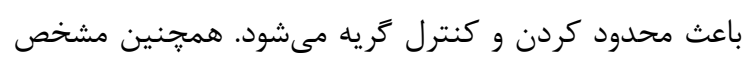

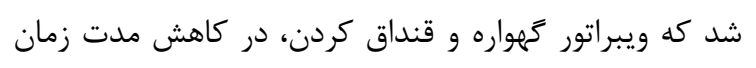

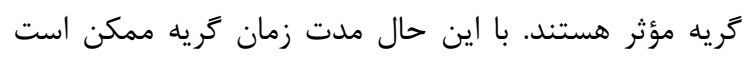

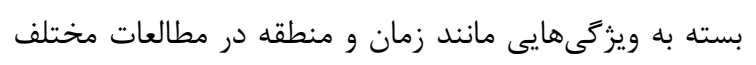
متفاوت باشد و نياز به يك ابزار جمع آورى دادئ ماده استاندارد براى تعيين مدت زمان كريه نوزادان وجود دارد (9) (\$). درمان هاى دارويى تعين مدت زمان تجويز سوكروز از جمله استراترىهاى درمانى داريى مطرح شده با

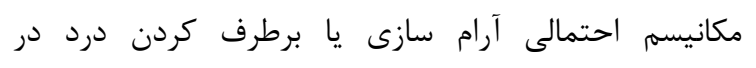

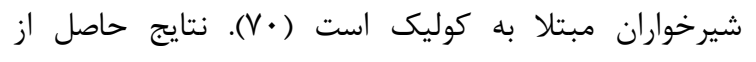

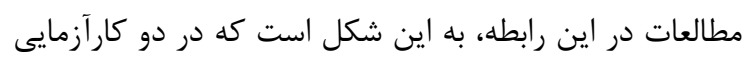

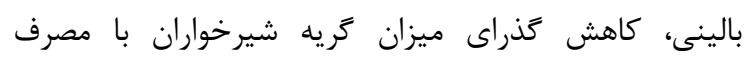

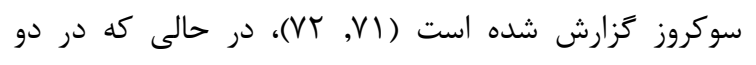

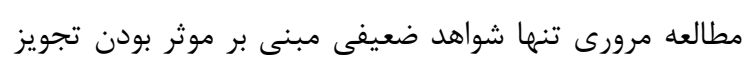
سوكروز مطرح شده است (VF, Nr).

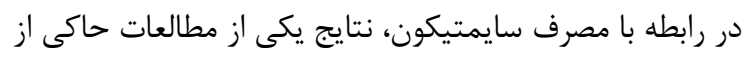

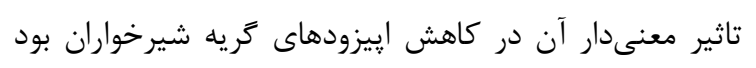

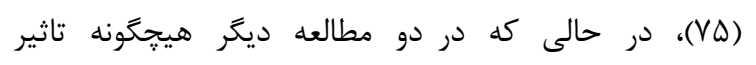
معنى دارى كزارش نشد (VQ)

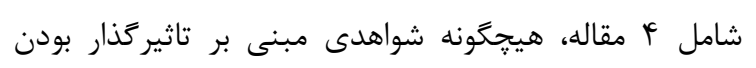

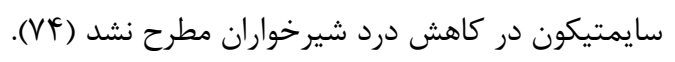


هستند كه باعث ديستانسيون معده و ديسترس ناشى از آن

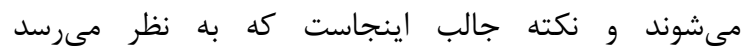

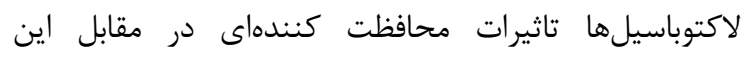

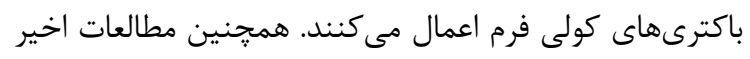

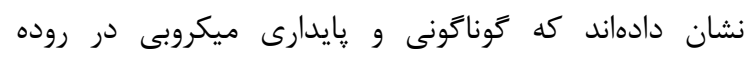

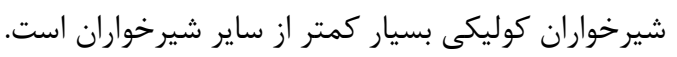
طى سالهاى اخير، با توجه به اينكه طى بلى برخى از از مطالعات،

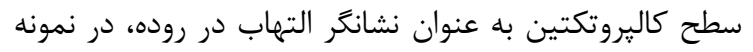

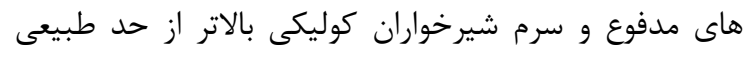
كزارش شده است، نقش ديس مدفيوز نيرخ ميكروبيال در ايجاد

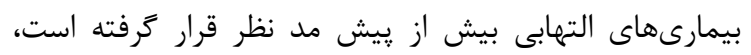

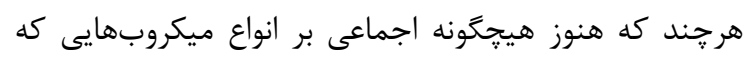

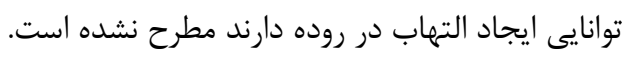
در راستاى مطرح شدن وجود احتمالى ارتباط بين ميكروبهاى

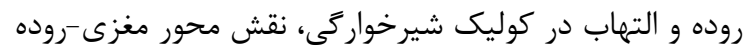

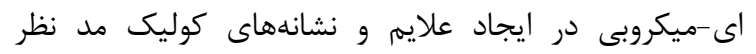

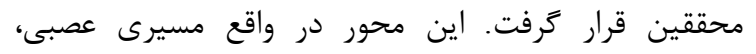

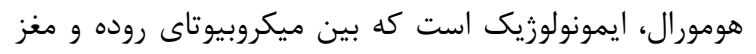

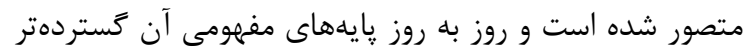

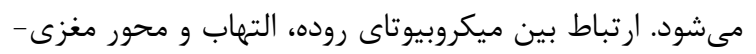

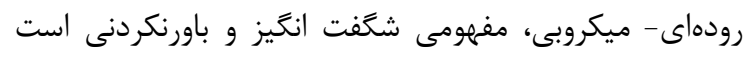

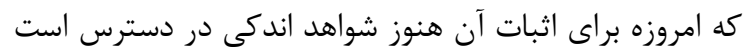

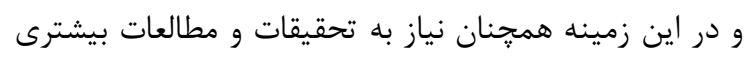

جهت تشخيص كوليك شيرخواركى طبق آنجه كَفته شده

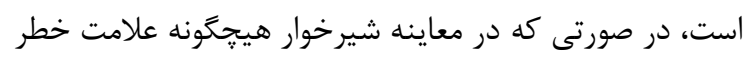

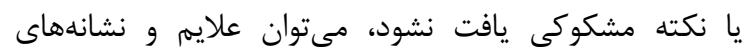

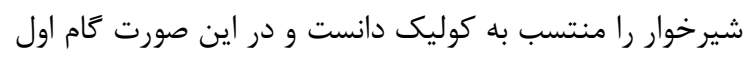
براى درمان شيرخوار، اطمينان بخشى و ارايه توضيحات لازم

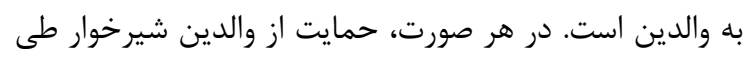

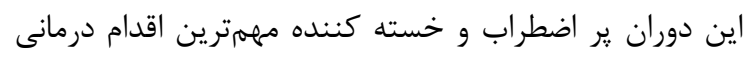
در سير درمان كوليك شيرخواركى است. لاكتوبايلوس روترى اضرى

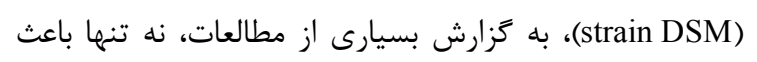

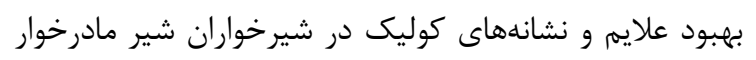

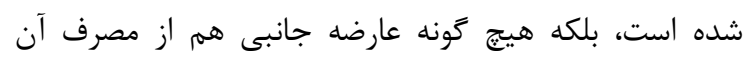

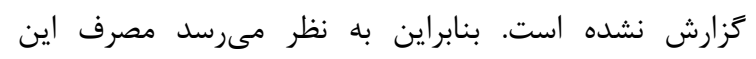

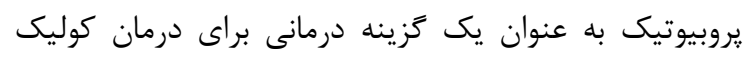

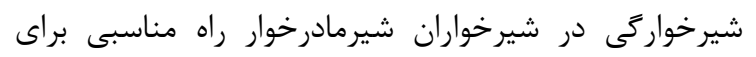

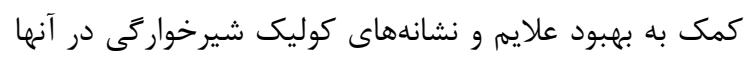

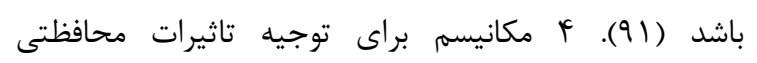

نشده است (N) و به طور كلى در حال حاضر جهت تصميم

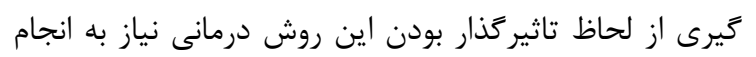
مطالعات بيشترى است.

استيوياتى با توجه به اطلاعات موجود در مورد علم استيوياتى، اين كونه

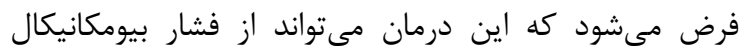

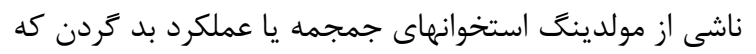

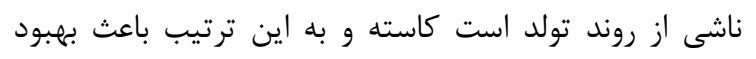

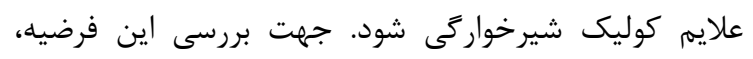

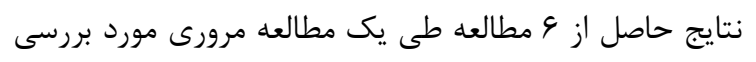

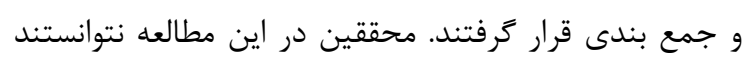

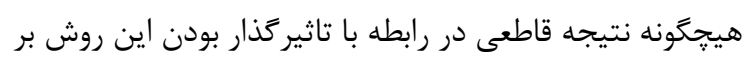
كاهش علايم كوليك شيرخواركى تزارش كنند (19).

طب انعكاسى على عليم

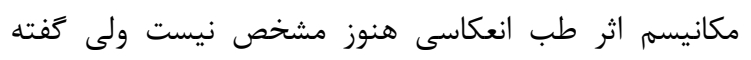

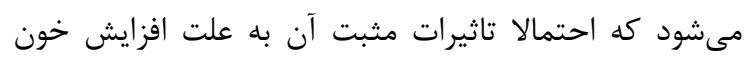

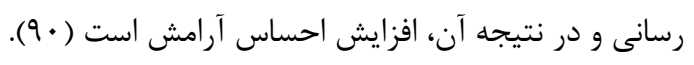

\section{بحث} به طور خلاصه، كوليك شيرخواركى يديدهاى شايع و اضطراب

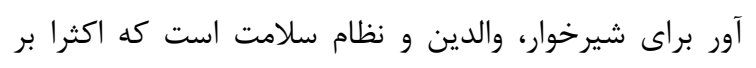

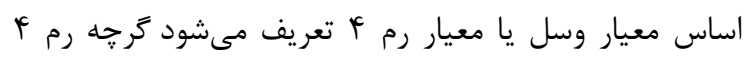

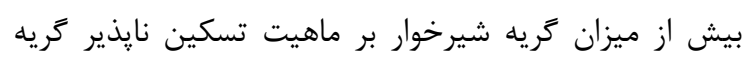

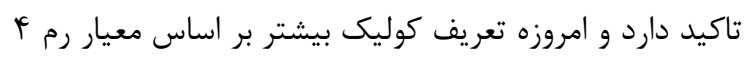

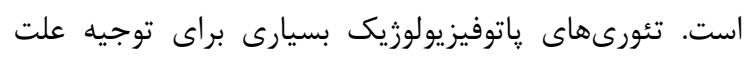

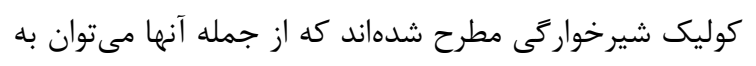

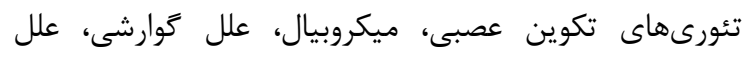

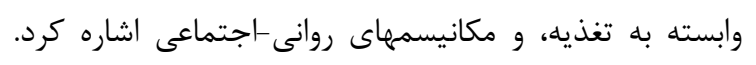

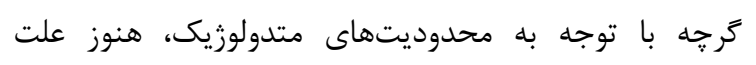

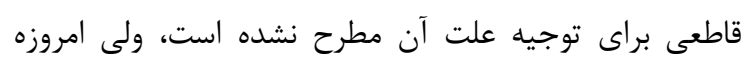
بحث بر سر تئورىهاى ميكروبى بيشتر از ساير تئوريها است.

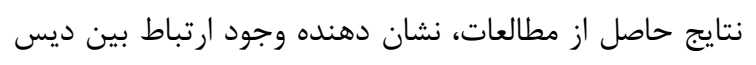

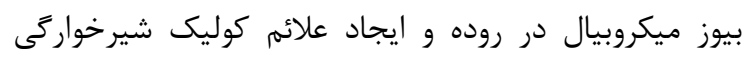
توسط محور مغزى-روده ای-ميكروبى است. محققين نشان دادهاند كه در شيرخواران مبتلا به كوليك، ميزان كلونيزاسيون

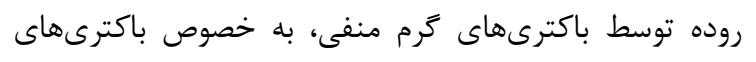

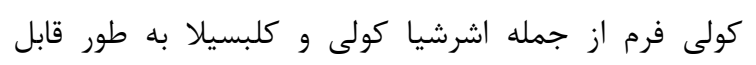

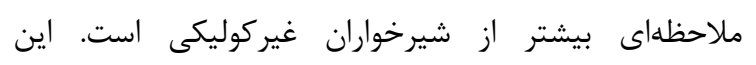

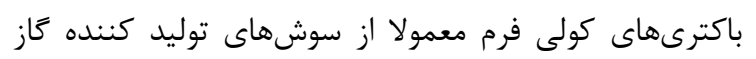


شير سويا در درمان كوليك شيرخوارگى پيشنهاد نمىشود (9ه). در ارتباط با استفاده از درمانهاى فيزيكى در درئ كنترل

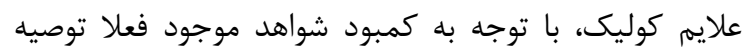

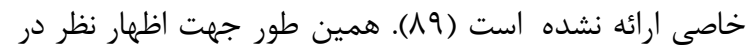
مورد تاثير استفاده از داروهاى گياهى (9)، مصرف سوكروز

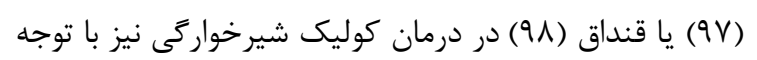
به كمبود شواهد موجود، نياز به انجام مطالعات بيشترى است.

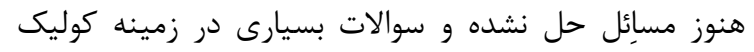

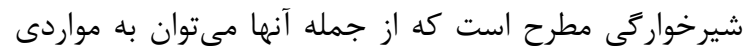

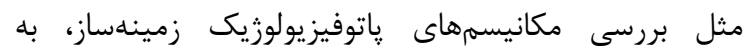

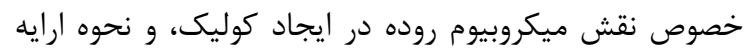
بهتر خدمات به خانوادههاى شيرخواران كوليكى اشاره كرد. براى ياسخ به اين سوالات نياز به ايجاد روشهاى بهرئ عينى بيشتر براى بررسى گريه شيرخوار و علايم رفتارى بهى (objective)

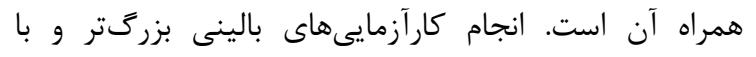

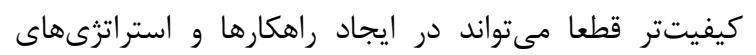

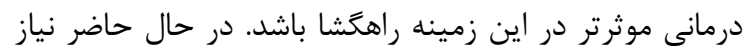

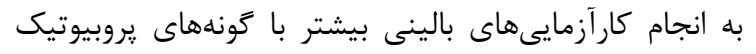

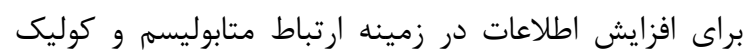
شيرخوارگى و ايجاد راهكارهاى درمانى مناسب براى درمان

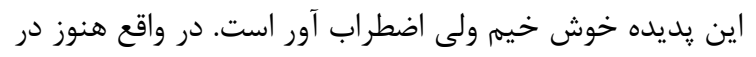
ابتداى مسير طولانى درك مفاهيمى جون ديس ديس بيون بيوز و ربيوز

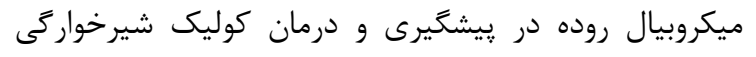

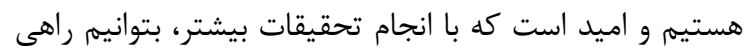
مناسب جهت ييشخيرى يا رفع اين مشكل فراهم آوريهم.
يروبيوتيكها مطرح شده است كه از جمله آنها مىتوان به

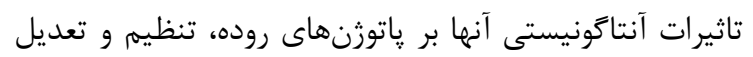

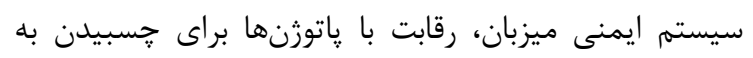

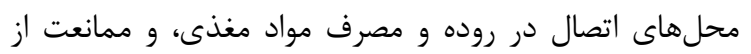
توليد يا عملكرد توكسينهاى باكتريها است. با وجود اينكه از سايمتيكون به طور شايعى براى درمان بان كوليك شيرخوارگى استفاده مىشود، مطالعات نشان دادهاند كه تاثير آن بر كاهش علايم كوليك بيش از تاثير يلاسبو نيست. لازم به ذكر است كه مصرف دى سيكلومين گرجه باعث كاهش علايم كوليك مى شود، با توجه به احتمال ايجاد آريتمى توسط اين دارو مصرف آن در شيرخواران با سن كمتر

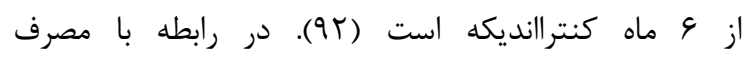
مهاركنندههاى يم״ يروتون براى كاهش علايم كوليك، نتايج

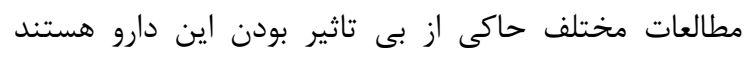

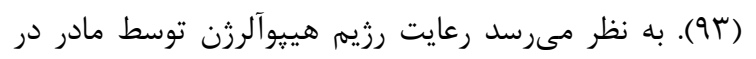

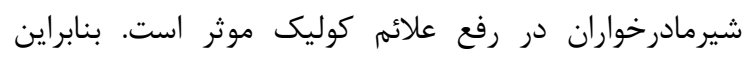

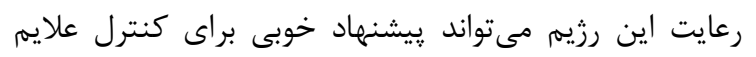

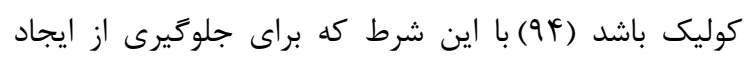
سوء تغذيه، رعايت اين رزيم حتما تحت نظر متخصصين تغذيه

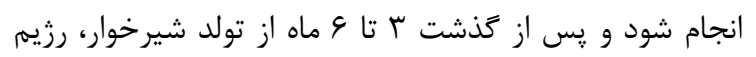

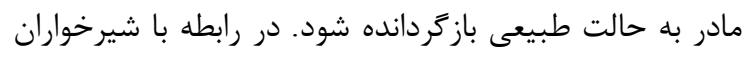

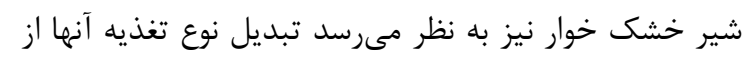

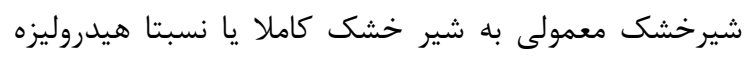

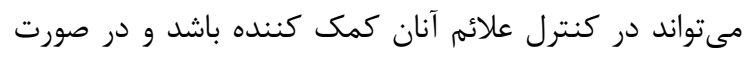

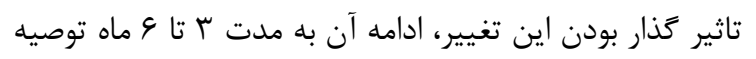

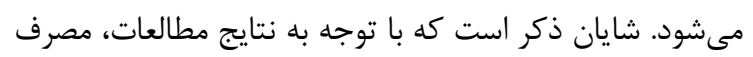

\section{REFERENCES}

1. Carey WB. "Colic"--primary excessive crying as an infant-environment interaction. Pediatr Clin North Am 1984;31:993-1005.

2. Sondheimer JM. New evidence on unexplained early infant crying: its origins, nature and management. J Pediatr Gastroenterol Nutr 2002;34:96-97.

3. Wessel MA, Cobb JC, Jackson EB, Harris GS, Detwiler AC. Paroxysmal fussing in infancy, sometimes called "colic". Pediatrics. 1954;14:421-35.

4. Zeevenhooven J, Browne PD, L'Hoir MP, de Weerth C, Benninga MA. Infant colic: mechanisms and management. Nat Rev Gastroenterol Hepatol 2018;15:479-496. doi: 10.1038/s41575-018-0008-7

5. Hyman PE, Milla PJ, Benninga MA, Davidson GP, Fleisher DF, Taminiau J. Childhood functional gastrointestinal disorders: neonate/toddler. Gastroenterology 2006;130:1519-26.

6. Vandenplas Y, Abkari A, Bellaiche M, Benninga M, Chouraqui JP, ÇokuĐrap F, et al. Prevalence and health outcomes of functional gastrointestinal symptoms in infants from birth to 12 months of age. J Pediatr Gastroenterol Nutr 2015;61:531.

7. Talachian E, Bidari A, Rezaie MH. Incidence and risk factors for infantile colic in Iranian infants. World J Gastroenterol 2008;14:4662-66. 
8. Botha E, Joronen K, Kaunonen M. The consequences of having an excessively crying infant in the family: an integrative literature review. Scand J Caring Sci 2019;33:779-790.

9. Bamber D, Powell C, Long J, Garratt R, Brown J, Rudge S, et al. Parental and health professional evaluations of a support service for parents of excessively crying infants. BMC Health Serv Res 2019;19:592.

10. Canivet C, Jakobsson I, Hagander B. Infantile colic. Follow-up at four years of age: still more "emotional". Acta Paediatr 2000;89:13-7.

11. Rautava P, Lehtonen L, Helenius H, Sillanpää M. Infantile Colic: Child and Family Three Years Later. Pediatrics 1995;96:43-47.

12. Rao MR, Brenner RA, Schisterman EF, Vik T, Mills JL. Long term cognitive development in children with prolonged crying. Arch Dis Child 2004;89:989-92.

13. Savino F, Castagno E, Bretto R, Brondello C, Palumeri E, Oggero R. A prospective 10-year study on children who had severe infantile colic. Acta paediatrica 2005;94:129-32.

14. Indrio F, Dargenio VN, Giordano P, Francavilla R. Preventing and Treating Colic. Adv Exp Med Biol 2019;1125:49-56.

15. Gosalbes MJ, Llop S, Vallès Y, Moya A, Ballester F, Francino MP. Meconium microbiota types dominated by lactic acid or enteric bacteria are differentially associated with maternal eczema and respiratory problems in infants. Clin Exp Allergy 2013;43:198-211.

16. Jost T, Lacroix C, Braegger CP, Chassard C. New insights in gut microbiota establishment in healthy breast fed neonates. PLoS ONE 2012;7: e44595. doi: 10.1371/journal.pone.0044595.

17. Ewaschuk JB, Naylor JM, Zello GA. D-Lactate in Human and Ruminant Metabolism. J Nutr 2005;135:1619-25.

18. Jiang T, Suarez FL, Levitt MD, Nelson SE, Ziegler EE. Gas Production by Feces of Infants. J Pediatr Gastroenterol Nutr 2001;32:534-41.

19. Tsubota-Matsunami M, Noguchi Y, Okawa Y, Sekiguchi F, Kawabata A. Colonic hydrogen sulfide-induced visceral pain and referred hyperalgesia involve activation of both $\mathrm{Ca}(\mathrm{v}) 3.2$ and TRPA1 channels in mice. J Pharmacol Sci 2012;119:293-96.

20. Pham VT, Lacroix C, Braegger CP, Chassard C. Lactate-utilizing community is associated with gut microbiota dysbiosis in colicky infants. Sci Rep 2017;7:11176.

21. de Weerth C, Fuentes S, Puylaert P, de Vos WM. Intestinal microbiota of infants with colic: development and specific signatures. Pediatrics. 2013;131:e550-8.

22. Rhoads JM, Fatheree NY, Norori J, Liu Y, Lucke JF, Tyson JE, et al. Altered fecal microflora and increased fecal calprotectin in infants with colic. J Pediatr 2009;155:823-8.e1.

23. Ewaschuk JB, Diaz H, Meddings L, Diederichs B, Dmytrash A, Backer J, et al. Secreted bioactive factors from Bifidobacterium infantis enhance epithelial cell barrier function. Am J Physiol Gastrointest Liver Physiol 2008;295:G1025-G34.

24. Chen ML, Takeda K, Sundrud MSJMI. Emerging roles of bile acids in mucosal immunity and inflammation. Mucosal Immunol 2019;12:851-861.

25. Camilleri M, Park SY, Scarpato E, Staiano A. Exploring hypotheses and rationale for causes of infantile colic. Neurogastroenterol Motil 2017;29.

26. Pavlidis P, Powell N, Vincent RP, Ehrlich D, Bjarnason I, Hayee B. Systematic review: bile acids and intestinal inflammation-luminal aggressors or regulators of mucosal defence? Aliment Pharmacol Ther 2015;42:802-17.

27. Riezzo G, Indrio F, Montagna O, Tripaldi C, Laforgia N, Chiloiro M, et al. Gastric electrical activity and gastric emptying in term and preterm newborns. Neurogastroenterol Motil 2000;12:223-29.

28. Thomas DW, McGilligan K, Eisenberg LD, Lieberman HM, Rissman EM. Infantile colic and type of milk feeding. Am J Dis Child 1987;141:451-53.

29. Lucas A, St James-Roberts I. Crying, fussing and colic behaviour in breast- and bottle-fed infants. Early Hum Dev 1998;53:9-18.

30. Azad MB, Konya T, Maughan H, Guttman DS, Field CJ, Chari RS, et al. Gut microbiota of healthy Canadian infants: profiles by mode of delivery and infant diet at 4 months. CMAJ 2013;185:385-94.

31. Matsuki T, Yahagi K, Mori H, Matsumoto H, Hara T, Tajima S, et al. A key genetic factor for fucosyllactose utilization affects infant gut microbiota development. Nat Commun 2016;7:11939. 
32. Gregory KE, Samuel BS, Houghteling P, Shan G, Ausubel FM, Sadreyev RI, et al. Influence of maternal breast milk ingestion on acquisition of the intestinal microbiome in preterm infants. Microbiome. 2016;4:68.

33. Chichlowski M, De Lartigue G, German JB, Raybould HE, Mills DA. Bifidobacteria isolated from infants and cultured on human milk oligosaccharides affect intestinal epithelial function. J Pediatr Gastroenterol Nutr 2012;55:321-27.

34. Reijneveld SA, van der Wal MF, Brugman E, Sing RA, Verloove-Vanhorick SP. Infant crying and abuse. Lancet 2004;364:1340-2.

35. Savino F, Galliano I, Garro M, Savino A, Daprà V, Montanari P, et al. Regulatory T cells and Toll-like receptor 2 and 4 mRNA expression in infants with colic treated with Lactobacillus reuteri DSM17938. Benef Microbes 20187;9:917-925.

36. Petzoldt J, Wittchen HU, Wittich J, Einsle F, Hofler M, Martini J. Maternal anxiety disorders predict excessive infant crying: a prospective longitudinal study. Arch Dis Child 2014;99:800-806.

37. Canivet CA, Ostergren PO, Rosen AS, Jakobsson IL, Hagander BM. Infantile colic and the role of trait anxiety during pregnancy in relation to psychosocial and socioeconomic factors. Scand J Public Health 2005;33:26-34.

38. Sondergaard C, Olsen J, Friis-Hasche E, Dirdal M, Thrane N, Sorensen HT. Psychosocial distress during pregnancy and the risk of infantile colic: a follow-up study. Acta Paediatrica 2003;92:811-16.

39. Heine RG, AlRefaee F, Bachina P, De Leon JC, Geng L, Gong S, et al. Lactose intolerance and gastrointestinal cow's milk allergy in infants and children-common misconceptions revisited. World Allergy Organ J 2017;10:41.

40. Iacovou M, Ralston RA, Muir J, Walker KZ, Truby HJM. Dietary management of infantile colic: a systematic review. Scand J Public Health 2012;16:1319-31.

41. Forsyth BWJTJop. Colic and the effect of changing formulas: a double-blind, multiple-crossover study. J Pediatr 1989;115:521-6.

42. hmed M, Billoo AG, Iqbal K, Memon A. Clinical efficacy of lactase enzyme supplement in infant colic: a randomised controlled trial. J Pak Med Assoc 2018;68:1744-1747.

43. Berkowitz D, Naveh Y, Berant M. Infantile colic" as the sole manifestation of gastroesophageal reflux. J Pediatr 1997;24:231-3.

44. Jordan B, Heine RG, Meehan M, Catto-Smith AG, Lubitz LJJop, health c. Effect of antireflux medication, placebo and infant mental health intervention on persistent crying: a randomized clinical trial. J Paediatr Child Health 2006;42:49-58.

45. Sutphen JL. Is it colic or is it gastroesophageal reflux? J Pediatr Gastroenterol Nutr 2001;33:110-11.

46. Sung V, St James-Roberts I, Editors. Infant colic. Pediatric Neurogastroenterology. New York: Springer; 2017. p. 369-79.

47. Ince $\mathrm{T}$, Akman $\mathrm{H}$, Çimrin $\mathrm{D}$, Aydın AJWJoP. The role of melatonin and cortisol circadian rhythms in the pathogenesis of infantile colic. World J Pediatr 2018;14:392-398.

48. Lai HC, Seal RP, Johnson JE. Making sense out of spinal cord somatosensory development. Development 2016;143:3434-48.

49. Freedman SB, Al-Harthy N, Thull-Freedman JJP. The crying infant: diagnostic testing and frequency of serious underlying disease. J Paediatr Child Health 2009;123:841-8.

50. Douglas P, Hill PJB. Managing infants who cry excessively in the first few months of life. BMJ 2011;343:d7772.

51. Johnson JD, Cocker K, Chang EJAFP. Infantile colic: recognition and treatment. Am Fam Physician 2015;92:57782.

52. Evans R, Allardyce R, Fergusson D, Taylor BJTL. Maternal diet and infantile colic in breast-fed infants. Lancet $1981 ; 317: 1340-42$.

53. Lam TML, Chan PC, Goh LH. Approach to infantile colic in primary care. Singapore Med J 2019;60:12-16.

54. Lucassen PL, Assendelft WJ, Gubbels JW, van Eijk JT, Douwes AC. Infantile colic: crying time reduction with a whey hydrolysate: A double-blind, randomized, placebo-controlled trial. Pediatrics 2000;106:1349-54.

55. Hall B, Chesters J, Robinson AJJop, health c. Infantile colic: a systematic review of medical and conventional therapies. J Paediatr Child Health 2012;48:128-37.

56. Moore RE, Townsend SD. Temporal development of the infant gut microbiome. Open Biol 2019;9:190128. 
57. Sebastiani G, Herranz Barbero A, Borrás-Novell C, Alsina Casanova M, Aldecoa-Bilbao V, Andreu-Fernández V, et al. The Effects of Vegetarian and Vegan Diet during Pregnancy on the Health of Mothers and Offspring. Nutrients 2019;11:E557.

58. Dryl R, Szajewska H. Probiotics for management of infantile colic: a systematic review of randomized controlled trials. Arch Med Sci. 2018;14:1137-43.

59. Harb T, Matsuyama M, David M, Hill RJJJopg, nutrition. Infant Colic-what works: a systematic review of interventions for breast-fed infants. J Pediatr Gastroenterol Nutr 2016;62:668-86.

60. Sung V, D’Amico F, Cabana MD, Chau K, Koren G, Savino F, et al. Lactobacillus reuteri to treat infant colic: a meta-analysis. Pediatrics 2018;141. pii: e20171811.

61. Indrio F, Di Mauro A, Riezzo G, Civardi E, Intini C, Corvaglia L, et al. Prophylactic use of a probiotic in the prevention of colic, regurgitation, and functional constipation: a randomized clinical trial. JAMA Pediatr 2014;168:228-33.

62. Ganguli K, Meng D, Rautava S, Lu L, Walker WA, Nanthakumar N. Probiotics prevent necrotizing enterocolitis by modulating enterocyte genes that regulate innate immune-mediated inflammation. Am J Physiol Gastrointest Liver Physiol 2013;304:G132-41.

63. Rodes L, Khan A, Paul A, Coussa-Charley M, Marinescu D, Tomaro-Duchesneau C, et al. Effect of probiotics Lactobacillus and Bifidobacterium on gut-derived lipopolysaccharides and inflammatory cytokines: an in vitro study using a human colonic microbiota model. J Microbiol Biotechnol 2013;23:518-26.

64. Szajewska H, Dryl R. Probiotics for the management of infantile colic. J Pediatr Gastroenterol Nutr 20161;63:S22-4.

65. Gill P, van Zelm M, Muir J, Gibson P. Short chain fatty acids as potential therapeutic agents in human gastrointestinal and inflammatory disorders .Aliment Pharmacol Ther 2018;48:15-34.

66. Langa S, Martín-Cabrejas I, Montiel R, Peirotén Á, Arqués JL, Medina MJFc. Protective effect of reuterinproducing Lactobacillus reuteri against Listeria monocytogenes and Escherichia coli O15:H7 in semi-hard cheese. J Microbiol Biotechnol 2018;84:284-89.

67. Bellaïche M, Levy M, Jung CJ, nutrition. Treatments for infant colic. J Pediatr Gastroenterol Nutr 2013;57:S27-S30.

68. Thomas SJ. Soothing crying babies and preventing shaken baby syndrome. J Pediatr Gastroenterol Nutr 2016;8:3438.

69. Möller EL, de Vente W, Rodenburg R. Infant crying and the calming response: Parental versus mechanical soothing using swaddling, sound, and movement. PLoS One 2019;14:e214548.

70. Matsuda E. Sucrose for analgesia in newborn infants undergoing painful procedures. Cochrane Database Syst Rev 2016; 2016: CD001069.

71. Markestad T. Use of sucrose as a treatment for infant colic. Arch Dis Child 1997;76:356-7.

72. Barr RG, Young SN, Wright JH, Gravel R, Alkawaf R. Differential calming responses to sucrose taste in crying infants with and without colic. Pediatrics 1999;103:e68.

73. Harb T, Matsuyama M, David M, Hill RJ. Infant Colic-What works: A Systematic Review of Interventions for Breast-fed Infants. J Pediatr Gastroenterol Nutr 2016;62:866-68.

74. Biagioli E, Tarasco V, Lingua C, Moja L, Savino F. Pain-relieving agents for infantile colic. The Cochrane database of systematic reviews. Cochrane Database Syst Rev. 2016;9:CD009999.

75. Leung AK, Lemay JF. Infantile colic: a review. J R Soc Promot Health 2004;124:162-66.

76. Danielsson B, Hwang CP. Treatment of infantile colic with surface active substance (simethicone). Acta Paediatr Scand 1985;74:446-50.

77. Metcalf TJ, Irons TG, Sher LD, Young PC. Simethicone in the treatment of infant colic: a randomized, placebocontrolled, multicenter trial. Pediatrics 1994;94:29-34.

78. Kanabar D, Randhawa M, Clayton P. Improvement of symptoms in infant colic following reduction of lactose load with lactase. J Hum Nutr Diet 2001;14:359-63.

79. Miller JJ, McVeagh P, Fleet GH, Petocz P, Brand JC. Effect of yeast lactase enzyme on "colic" in infants fed human milk. J Pediatr 1990;117:261-3.

80. Stahlberg MR, Savilahti E. Infantile colic and feeding. Arch Dis Child 1986;61:1232-3.

81. Bellaïche M, Levy M, Jung C. Treatments for infant colic. J Pediatr Gastroenterol Nutr 2013;57:S27-30. 
82. Savino F, Cresi F, Castagno E, Silvestro L, Oggero R. A randomized double-blind placebo-controlled trial of a standardized extract of Matricariae recutita, Foeniculum vulgare and Melissa officinalis (ColiMil) in the treatment of breastfed colicky infants. Phytother Res 2005;19:335-40.

83. Mohammadi Gh, Ghazanfarpour M, Kargarfard L, Babakhanian M. Effectiveness of herbal medicines containing phytoestrogens to treat infantile colic: a meta-analysis review. Journal of Pediatrics Review 2019; 7:1-10.

84. Tnah L, Lee S, Tan A, Lee C, $\mathrm{Ng} \mathrm{K}, \mathrm{Ng} \mathrm{C}$, et al. DNA barcode database of common herbal plants in the tropics: a resource for herbal product authentication. Food Control 2019;95:318-26.

85. Cui KM, Li WM, Gao X, Chung K, Chung JM, Wu GC. Electro-acupuncture relieves chronic visceral hyperalgesia in rats. Neurosci Lett 2005;376:20-23.

86. Liao JM, Lin CF, Ting H, Chang CC, Lin YJ, Lin TB. Electroacupuncture at Hoku elicits dual effect on autonomic nervous system in anesthetized rats. Neurosci Lett 2002; 42: 15-20.

87. Reinthal M, Andersson S, Gustafsson M, Plos K, Lund I, Lundeberg T, et al. Effects of minimal acupuncture in children with infantile colic- a prospective, quasi-randomised single blind controlled trial. Acupunct Med 2008;26:171-82.

88. Skjeie H, Skonnord T, Fetveit A, Brekke M. Acupuncture for infantile colic: a blinding-validated, randomized controlled multicentre trial in general practice. Scand J Primary Health Care 2013;31:190-6.

89. Dobson D, Lucassen PL, Miller JJ, Vlieger AM, Prescott P, Lewith G. Manipulative therapies for infantile colic. Cochrane Database Syst Rev 2012;12:CD004796.

90. Bennedbaek O, Viktor J, Carlsen KS, Roed H, Vinding H, Lundbye-Christensen S. Infants with colic. A heterogenous group possible to cure? Treatment by pediatric consultation followed by a study of the effect of zone therapy on incurable colic. Ugeskr Laeger 2001;163:3773-78. [In Danish]

91. Savino F, Pelle E, Palumeri E, Oggero R, Miniero R. Lactobacillus reuteri (American Type Culture Collection Strain 55730) versus simethicone in the treatment of infantile colic: a prospective randomized study. Pediatrics 2007;119:e124-30

92. Williams J, Watkins-Jones R. Dicyclomine: worrying symptoms associated with its use in some small babies. BMJ 1984;288:901.

93. Moore DJ, Tao BS, Lines DR, Hirte C, Heddle ML, Davidson GP. Double-blind placebo-controlled trial of omeprazole in irritable infants with gastroesophageal reflux. J Pediatr 2003;143:219-23.

94. Hill DJ, Roy N, Heine RG, Hosking CS, Francis DE, Brown J, et al. Effect of a low-allergen maternal diet on colic among breastfed infants: a randomized, controlled trial. Pediatrics 2005;116:e709-e15.

95. Iacovou M, Ralston RA, Muir J, Walker KZ, Truby H. Dietary management of infantile colic: a systematic review. Matern Child Health J 2012;16:1319-31.

96. Perry R, Hunt K, Ernst E. Nutritional supplements and other complementary medicines for infantile colic: a systematic review. Pediatrics 2011;127:720-33.

97. Arikan D, Alp H, Gözüm S, Orbak Z, Cifçi EK. Effectiveness of massage, sucrose solution, herbal tea or hydrolysed formula in the treatment of infantile colic. J Clin Nurs 2008;17:1754-61.

98. Van Sleuwen B, L'hoir M, Engelberts A, Busschers W, Westers P, Blom M, et al. Comparison of behavior modification with and without swaddling as interventions for excessive crying. J Pediatr 2006;149:512-7. 